\title{
29. TERTIARY CALCAREOUS NANNOPLANKTON FROM THE WESTERN EQUATORIAL PACIFIC
}

\author{
E. Martini, Geologisch-Paläontologisches Institut der Universität Frankfurt a.M., Germany \\ and \\ T. Worsley, Department of Oceanography, University of Washington, Seattle, Washington
}

\section{INTRODUCTION}

Calcareous nannoplankton from pre-Quaternary sediments have been reported and described from various places in the Pacific Ocean, but investigations were based on isolated samples or short cores (Bramlette, 1961; Kamptner, 1963; Riedel and Funnell, 1964; Martini, 1965; Haq, 1969). During the experimental Mohole drilling near Guadalupe Island a number of cores were recovered from the Pliocene down to the lower part of Middle Miocene; here for the first time the calcareous nannoplankton could be studied in a more or less continuous sequence (Martini and Bramlette, 1963).

With the introduction of the Deep Sea Drilling Project a number of continuous sections in the Pacific Ocean were recovered during Legs 5 and 6 . In the following, the calcareous nannoplankton obtained during Leg 7 from the sequences in the western equatorial Pacific are described and discussed.

\section{LOCALITIES AND STRATA RECOVERED}

During Leg 7 of the Deep Sea Drilling Project holes were drilled at seven sites. Material recovered from Sites 61 and 67 did not contain calcareous nannoplankton; geographical positions of the remaining DSDP sites are as follows (Figure 1):

$\begin{array}{ll}\text { DSDP } 62 & \text { lat. } 1^{\circ} 52.2^{\prime} \mathrm{N} \text {, long. } 141^{\circ} 56.3^{\prime} \mathrm{E} \text {. } \\ \text { DSDP } 63 & \text { lat. } 0^{\circ} 50.16^{\prime} \mathrm{N} \text {, long. } 147^{\circ} 53.25^{\prime} \mathrm{E} \text {. } \\ \text { DSDP } 64 & \text { lat. } 1^{\circ} 44.5^{\prime} \mathrm{S} \text {, long. } 158^{\circ} 36.5^{\prime} \mathrm{E} \text {. } \\ \text { DSDP } 65 & \text { lat. } 4^{\circ} 21.21^{\prime} \mathrm{N} \text {, long. } 176^{\circ} 59.16^{\prime} \mathrm{E} \text {. } \\ \text { DSDP } 66 & \text { lat. } 2^{\circ} 23.63^{\prime} \mathrm{N} \text {, long. } 166^{\circ} 07.28^{\prime} \mathrm{W} \text {. }\end{array}$

In Hole $62-0$ the terminal depth was 581 meters, and the lowest of seven cores was drilled into basalt containing chalky lumps with calcareous nannoplankton of Zone NP 24. In Hole 62-1 the terminal depth was 364 meters, and a continuous calcareous sequence was recovered yielding calcareous nannoplankton of Zones NN 21 down to $\mathrm{NN} \mathrm{4,} \mathrm{with} \mathrm{the} \mathrm{exception} \mathrm{of} \mathrm{Zone}$ NN 15.

At Site 63, three holes were drilled, of which Hole 63-0 was terminated when Core 11 reached basalt at a depth of 566 meters. Sediment from above the basalt yielded calcareous nannoplankton of Zone NP 23. Two continuous sequences were drilled in Hole 63-1 with Pliocene nannoplankton (Zone NN 18 to NN 14) in the upper four cores and Middle to Lower Miocene nannoplankton (Zones NN 9 to NN 4) in the lower ten cores. Terminal depth was 193 meters. Three cores of Hole 63-2 repeated down to 39 meters the Pliocene sequence found in Hole 63-1.

Two holes were drilled at Site 64. In Hole 64-0, ten cores were recovered down to the terminal depth of 851 meters, yielding calcareous nannoplankton of Zone NP 24 in the lowest core. In the second hole (64-1) a continuous sequence of five cores was obtained from the lowest Middle Miocene to the highest Lower Miocene (Zones NN 5 to NN 4), and the following survey-coring (seven cores) reached 985 meters, where drilling was terminated in cherty limestone of early Upper Eocene age (standard calcareous nannoplankton Zone NP 16).

At Site 65, sediments recovered in two holes proved to be noncalcareous, except for an interval in the lower part of Hole 65-0 (terminal depth 145 meters), where in Cores 14 to 16 Lower Oligocene and Upper Eocene nannoplankton (Zones NP 21 and NP 17) have been found, and in part of Hole 65-1 (Cores 2 and 3 ) with nannoplankton of Zone NP 17 present.

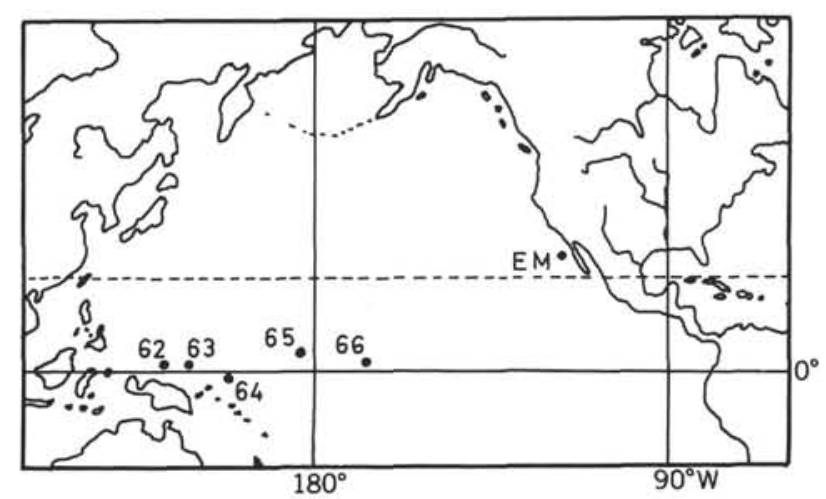

Figure 1. Sites from which calcareous nannoplankton assemblages have been studied. 
Sediments recovered in two holes of Site 66 also proved to be noncalcareous, except for a short interval in Core 2 of Hole 66-0 (lower half of Section 2 and several layers in Section 3), where an assemblage of discoasters and some other remains of the calcareous nannoplankton showing signs of heavy solution may represent Zone NN 5 or NN 6.

\section{PALEOGENE CALCAREOUS NANNOPLANKTON ZONES IN MATERIAL RECOVERED}

The zonation used is the standard Paleogene calcareous nannoplankton zonation (Martini, 1970). A short definition is given together with NP number and name for each zone represented by material recovered at Sites 62 , 63,64 and 65 . As discussed above the base of Zone NN 1 is within the uppermost Oligocene according to the definition of the Paleogene/Neogene boundary corresponding to the Globigerinoides datum of the planktonic foraminiferal zonation. Complete sequences have not been cored in the Paleogene, therefore the only boundary found is that between NP 25 and NP 24 in Hole 64-0.

\section{NP 25 - Sphenolithus ciperoensis Zone}

Definition: Interval from the last occurrence of Sphenolithus distentus (Martini) to the last occurrence of Helicopontosphaera truncata (Bramlette and Wilcoxon).

Samples: $64-0$, Core 8 , Section $1(40-41 \mathrm{~cm})$ to Section $3(125-176 \mathrm{~cm})$.

Common species: Triquetrorhabdulus carinatus Martini, Sphenolithus pacificus Martini, Sphenolithus ciperoensis Bramlette and Wilcoxon, Coccolithus aff. pelagicus (Wallich), Discoaster deflandrei Bramlette and Riedel, Dictyococcites dictyodus (Deflandre and Fert).

Remarks: Helicopontosphaera truncata has not been found as yet in these samples, but all Oligocene and Lower Miocene Helicopontosphaera species seem to be rare in the equatorial Pacific. Sphenolithus belemnos Bramlette and Wilcoxon may prove to be of some help, as first specimens seem to appear near the base of NN 1.

\section{NP 24 - Sphenolithus distentus Zone}

Definition: Interval from the first Sphenolithus ciperoensis Bramlette and Wilcoxon to the last occurrence of Sphenolithus distentus (Martini).

Samples: $62-0$, Cores 7 and 8; 63-0, Cores 6 to 8 ; 64-0, Core 8 -CC and Cores 9 to $10 ; 64-1$, Core 8 .

Common species: Sphenolithus distentus (Martini), Sphenolithus predistentus Bramlette and Wilcoxon,
Sphenolithus pacificus Martini, Discoaster deflandrei, Bramlette and Riedel, Dictyococcites dictyodus (Deflandre and Fert), Coccolithus aff. pelagicus (Wallich), less common Discoaster lidzi Hay, Sphenolithus ciperoensis Bramlette and Wilcoxon, Helicopontosphaera truncata (Bramlette and Wilcoxon), Zygrhablithus bijugatus (Deflandre), Coccolithus eopelagicus (Bramlette and Riedel), Ericsonia fenestrata (Deflandre and Fert), Helicopontosphaera compacta (Bramlette and Wilcoxon), Helicopontosphaera euphratis Haq (= syn. $H$. parallela Bramlette and Wilcoxon).

Remarks: $H$. recta and $H$. euphratis have been found only in $62-0$, Core $8-\mathrm{CC}, \mathrm{H}$. truncata also in some other samples.

\section{NP 23 - Sphenolithus predistentus Zone}

Definition: Interval from the last occurrence of Reticulofenestra umbilica (Levin) to the first occurrence of Sphenolithus ciperoensis Bramlette and Wilcoxon.

Samples: 63-0, Cores 9 to 11 .

Common species: Sphenolithus predistentus Bramlette and Wilcoxon, Sphenolithus pacificus Martini, Dictyococcites dictyodus (Deflandre and Fert), Coccolithus aff. pelagicus (Wallich), Coccolithus eopelagicus (Bramlette and Riedel), Discoaster deflandrei Bramlette and Riedel, less common Sphenolithus distentus (Martini), Ericsonia fenestrata (Deflandre and Fert), Discoaster tani Bramlette and Riedel, Helicopontosphaera compacta (Bramlette and Wilcoxon).

NP 21 - Ericsonia? subdisticha Zone

Definition: Interval from the last occurrence of Discoaster saipanensis Bramlette and Riedel to the last occurrence of Ericsonia? subdisticha (Roth and Hay).

Samples: $65-0$, Core 14, Section $3(149-150 \mathrm{~cm})$ to Core 14-CC.

Common species: Ericsonia ? subdisticha (Roth and Hay), Cyclococcolithus formosus Kamptner, Reticulofenestra umbilica (Levin), Coccolithus eopelagicus (Bramlette and Riedel), Sphenolithus pacificus Martini, Discoaster deflandrei Bramlette and Riedel, Discoaster tani Bramlette and Riedel, Dictyococcites dictyodus (Deflandre and Fert), less common Sphenolithus predistentus Bramlette and Wilcoxon, Helicopontosphaera reticulata (Bramlette and Wilcoxon).

Remarks: Isthmolithus recurvus Deflandre as well as Rhabdosphaera species seem to be absent in this region. At Site 65 Upper Eocene calcareous 
nannoplankton have been introduced by turbidity currents into Zone NP 21.

\section{NP 20 - Sphenolithus pseudoradians Zone}

Definition: Interval from the first occurrence of Sphenolithus pseudoradians Bramlette and Wilcoxon to the last occurrence of Discoaster saipanensis Bramlette and Riedel.

Samples: $64-1$, Core 9.

Common species: Discoaster barbadiensis Tan Sin Hok, Discoaster saipanensis Bramlette and Riedel, Discoaster tani Bramlette and Riedel, Cyclococcolithus formosus Kamptner, Dictyococcites dictyodus (Deflandre and Fert), Reticulofenestra umbilica (Levin), Coccolithus eopelagicus (Bramlette and Riedel), less common Sphenolithus pseudoradians Bramlette and Wilcoxon, Sphenolithus pacificus Martini, Cyclococcolithus reticulatus Gartner and Smith, Helicopontosphaera intermedia (Martini), Helicopontosphaera compacta (Bramlette and Wilcoxon).

Remarks: Isthmolithus recurvus Deflandre as well as Rhabdosphaera species and Lanthernithus minutus Stradner obviously missing in this area.

\section{NP 17 - Discoaster saipanensis Zone}

Definition: Interval from the last occurrence of Chiasmolithus solitus (Bramlette and Sullivan) to the first occurrence of Chiasmolithus oamaruensis (Deflandre).

Samples: $64-1$, Core $10 ; 65-0$, Cores 15 and $16 ; 65-1$, Cores 2 and 3.

Common species: Discoaster barbadiensis Tan Sin Hok, Discoaster saipanensis Bramlette and Riedel, Discoaster tani tani Bramlette and Riedel, Discoaster tani nodifer Bramlette and Riedel, Reticulofenestra umbilica (Levin), Dictyococcites dictyodus (Deflandre and Fert), Coccolithus eopelagicus (Bramlette and Riedel), less common Discoaster binodosus Martini, Chiasmolithus grandis (Bramlette and Riedel), Sphenolithus pacificus Martini, Discoaster deflandrei Bramlette and Riedel, Cyclococcolithus formosus Kamptner, Sphenolithus radians Deflandre, Chiasmolithus gigas (Bramlette and Sullivan).

Remarks: All species of the Zygolithus dubius group seem to be absent in this area.

\section{NP 16 - Discoaster tani nodifer Zone}

Definition: Interval from the last occurrence of Rhabdosphaera gladius Locker to the last occurrence of Chiasmolithus solitus (Bramlette and Sullivan).

Samples: 64-1, Core 11.
Common species: Discoaster barbadiensis Tan Sin Hok, Chiasmolithus solitus (Bramlette and Sullivan), Discoaster tani nodifer Bramlette and Riedel, Coccolithus eopelagicus (Bramlette and Riedel), Sphenolithus cf.pacificus Martini, less common Cyclococcolithus formosus Kamptner, Reticulofenestra umbilica (Levin), Sphenolithus radians Deflandre, Chiasmolithus grandis (Bramlette and Riedel), Helicopontosphaera lophata (Bramlette and Sullivan).

Remarks: Zygolithus dubius Deflandre, common in this zone in other areas, seems to be absent in the equatorial region.

\section{PRESERVATION OF CALCAREOUS NANNOFOSSILS}

Preservation of nannofossils is generally fair to excellent in all cores in which calcareous material is present. Distinctive species are recognizable in all cases but preservation usually becomes poorer with depth.

Coccoliths are more resistant to secondary calcification than discoasters. The reasons for this are not clearly understood but the relatively simple construction of the discoasters compared with that of the coccoliths may play a part. Coccolith shields are commonly constructed of 20 to 100 radial elements which are tightly sutured, and therefore present relatively small surface areas of single crystals on which secondary overgrowth can occur. When it does, the overall outline and construction of the coccolith is preserved quite well, much of the modification being on a scale too small to be resolved in the light microscope. Discoasters, on the other hand, are usually constructed of only 5 or 6 rays which are sutured only in a relatively small central area. Each ray, therefore, presents a single calcite crystal with a large, exposed surface area on which overgrowth may take place. This is evident on electron micrographs in which several of the rays of a single specimen have a prismatic outline, whereas the remainder of the rays still exhibit varying degrees of their original outlines. There may also be a basic difference in chemical composition between the coccoliths and discoasters, or the coccoliths may retain the membranous organic coating they possess when the entire organism is living, but both these possibilities have yet to be demonstrated.

Following is a summary of the preservation encountered at sites where calcareous material was recovered. Sphenoliths and Triquetrorhabdulus are included within the discoasters for purposes of discussion, as both are similar in preservational qualities.

Site 62

Coccoliths are well-preserved throughout the section but discoasters show slight effects of secondary calcification below 120 meters. Below 350 meters to the 
terminal depth of 581 meters, discoasters show moderate overgrowth and recrystallization but most of the more distinctive species are recognizable throughout the section.

\section{Site 63}

In the upper 65 meters of this site, both discoasters and coccoliths have suffered slight to moderate solution but species are easily recognizable. Between 65 and 140 meters, preservation is excellent for both groups; but, below this discoasters show increasing recrystallization and secondary calcification with depth. They become moderately overgrown at about 350 meters and remain so until the terminal depth of 566 meters. However, the more distinctive species are always recognizable.

\section{Site 64}

Preservation is adequate for both discoasters and coccoliths throughout the section. Discoasters show slight secondary calcification at 200 meters, but preservation for both groups is good at $\mathbf{3 0 0}$ meters. Discoasters become progressively more recrystallized with depth from this point and are moderately overgrown at the terminal depth of 980 meters.

\section{Sites 65 and 66}

The cores are mostly noncalcareous but contain abundant recrystallized discoasters in a few calcareous layers. Preservation of coccoliths is fair.

\section{NEOGENE CALCAREOUS NANNOPLANKTON ZONES IN MATERIAL RECOVERED}

All zones of the standard Neogene calcareous nannoplankton zonation (Martini and Worsley, 1970) are represented, although some are exceedingly thin in the Western Pacific. Table 1 summarizes the definition of each of these zones.

An almost complete sequence from Lower Middle Miocene to Recent was cored in Hole 62-1 and another from just above the base of the Neogene to the Upper Middle Miocene was recovered from Hole 63-1. The combined material from these two holes permits very precise determination of highest and lowest occurrences of many well known species of calcareous nannofossils from the Neogene, and offers a basis for subdivision of the present zonation which should increase biostratigraphic resolution to 0.5 million years using present methods.

\section{STRATIGRAPHIC DISTRIBUTION OF SELECTED NANNOFOSSIL SPECIES}

The stratigraphic distribution of some calcareous nannofossil species is presented in Tables 2 through 8 . Selection of species is arbitrary and probably includes less than 25 per cent of the named taxa present in the cores. Emphasis has been placed on Neogene species, but information about several Paleogene species is also included. All lowest and highest occurrences have been determined to within half a section (about one meter) where possible. Location of samples to the nearest centimeter within a section may be found by consulting the detailed descriptions of the cores and the sample appendix.

The following symbols are used on Tables 2 through 8 :

$$
\begin{aligned}
X= & \text { abundant }(\text { more than one specimen } \\
& \text { per field of view at } 1000 \times) ; \\
\circ= & \text { common }(\text { one specimen per } 1 \text { to } 10 \\
& \text { fields of view at } 1000 \times) ; \\
\bullet= & \text { rare (less than one specimen per } 10 \\
& \text { fields of view at } 1000 \times) ; \\
\sim= & \text { probably present but poor preserva- } \\
& \text { tion does not permit reliable deter- } \\
& \text { mination; } \\
c f= & \text { resembles, but is not identical to; } \\
\text { ace }= & \text { species not looked for; } \\
-= & \text { species looked for and not found. }
\end{aligned}
$$$$
\text { blank space }=\text { species not looked for; }
$$

Searching was arbitrarily cut off at 200 fields of view. With an average number of 30 specimens per field, this represents a scanning of 6000 specimens. The possibility exists that lowest and highest occurrences determined by another worker using different searching criteria will not be identical to those found here, but differences should be minor (e.g., within a section).

It should be noted that lowest occurrence determinations are usually more precise because many species of nannofossils proliferate shortly after they evolve and slowly dwindle to extinction thereafter, rendering determination of highest occurrences more difficult and subjective.

\section{DISCUSSION OF IMPORTANT SPECIES IN THE WESTERN PACIFIC}

Following is a brief discussion of the characteristics of 49 nannofossil species from cores obtained on Leg 7. This is not intended to be a systematic paleontology section, but rather an aid in determination of relative stratigraphic usefulness of species, as well as a tabulation of their occurrences. All species are listed in alphabetical order and no attempt at suprageneric classification is made. Excellent suprageneric classifications have been presented by Gartner (1968) and Hay (1970). The reader is referred to these. References for the original descriptions and figures of species, as well as synonomy, is contained in the annotated index and bibliography of the calcareous nannoplankton (Loeblich and Tappan, $1966,1968,1969)$. Those not in the annotated bibliography may be found in Hay (1970). 
TABLE 1

Standard Neogene Calcareous Nannoplankton Zonation (after Martini and Worsley, 1970)

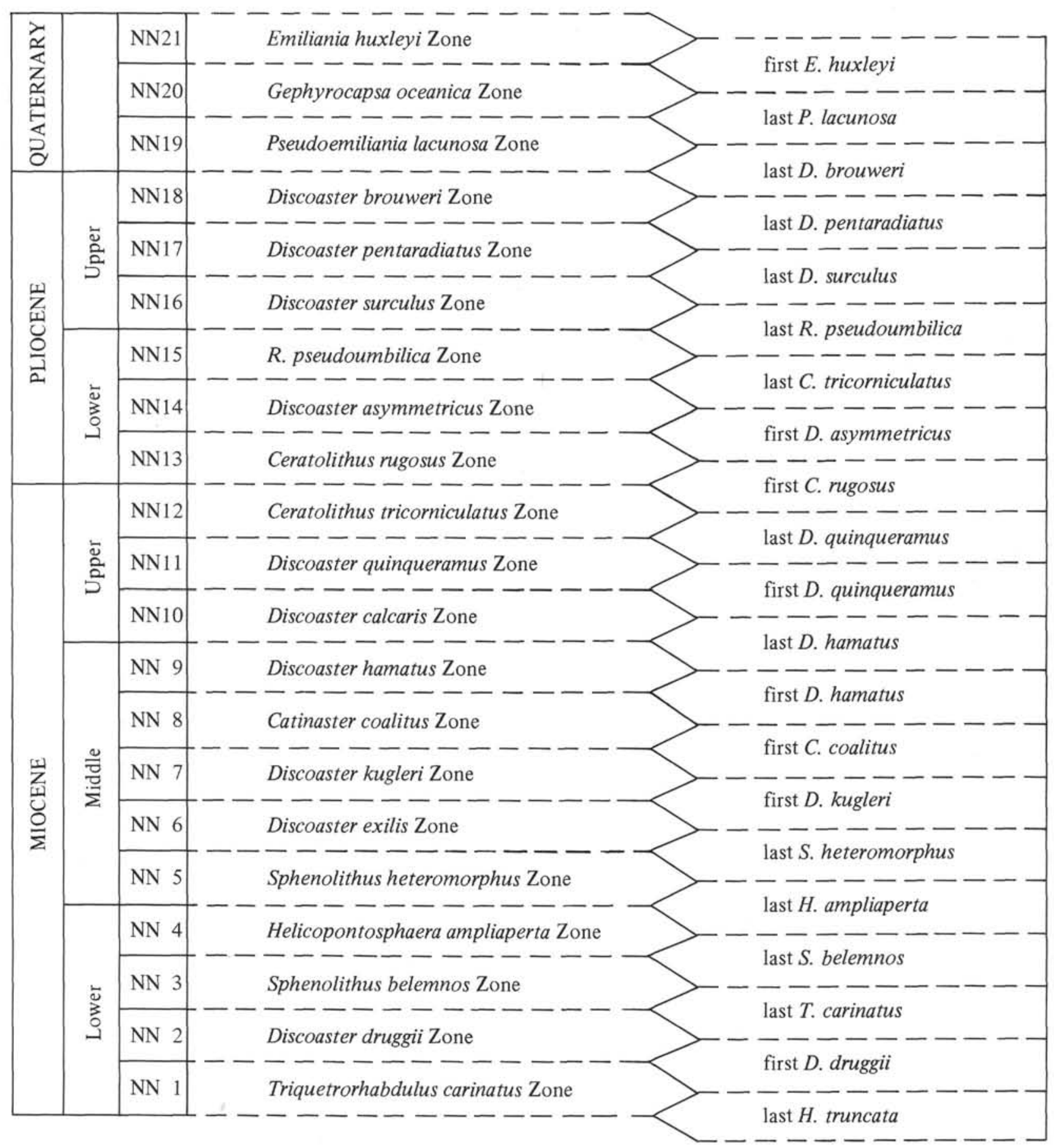


TABLE 2

Distribution of Calcareous Nannofossils in Cores from Hole 62-0

\begin{tabular}{|c|c|c|c|c|c|c|c|c|c|c|c|}
\hline 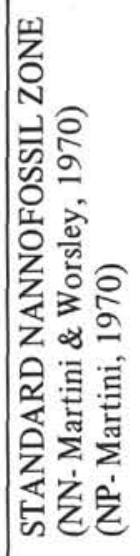 & $\begin{array}{c}\text { Sample } \\
\text { Designation }\end{array}$ & 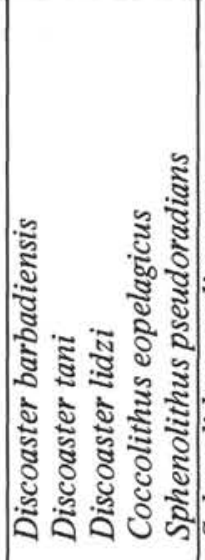 & 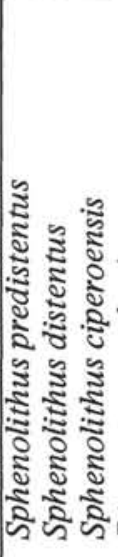 & 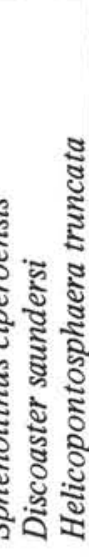 & 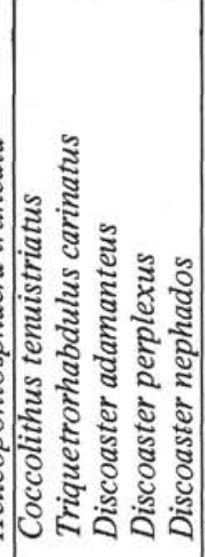 & 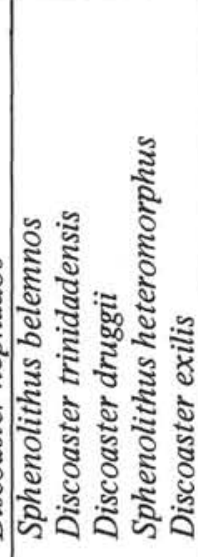 & 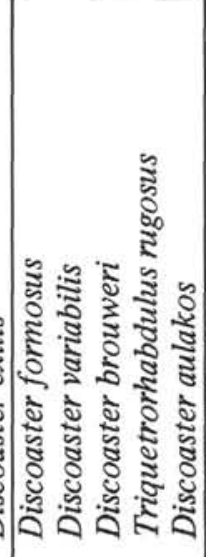 & 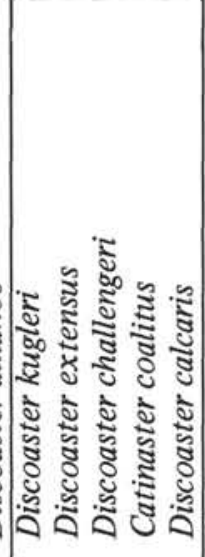 & 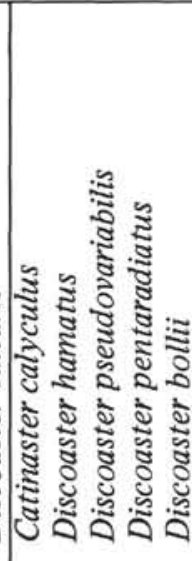 & 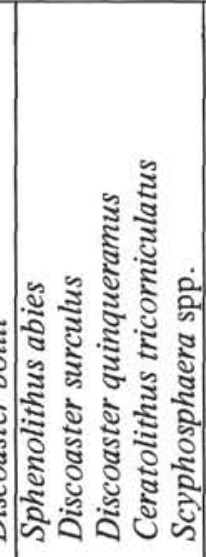 & 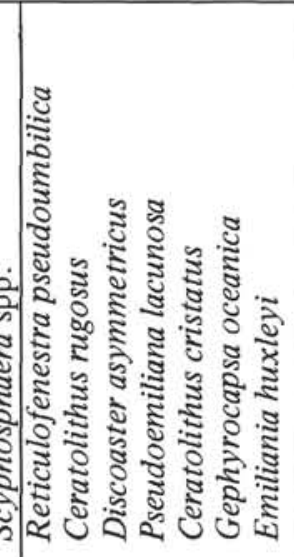 \\
\hline $\begin{array}{c}\text { NN } \\
14-15\end{array}$ & $\begin{array}{l}62-0-1-1,25 \\
62-0-1-6,123\end{array}$ & & & & & & $\begin{array}{ll}0 & 0 \\
0 & 0\end{array}$ & $\begin{array}{lll}0 & \bullet \\
0 & \bullet\end{array}$ & $\begin{array}{l}0 \\
0\end{array}$ & $\begin{array}{lll}0 & 0 & \\
x & \bullet & \end{array}$ & $\begin{array}{lll}0 & \bullet & 0 \\
0 & \bullet & 0\end{array}$ \\
\hline NN11 & $\begin{array}{l}62-0-2-1,138 \\
62-0-2-6,127\end{array}$ & & & & $\bullet$ & & $\begin{array}{l}\tau \\
\tau \\
\tau\end{array}$ & $\circ \ddot{\bullet} \bullet$ & $\begin{array}{l}\tau \\
0\end{array}$ & 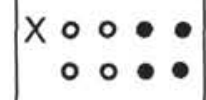 & \\
\hline NN 9 & $\begin{array}{l}62-0-3-1,26 \\
62-0-3-6,125\end{array}$ & & & & $\bullet \quad \bullet$ & & 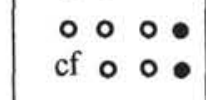 & $\begin{array}{llll}\circ & \circ & 0 & \bullet \\
\circ & \bullet & 0\end{array}$ & 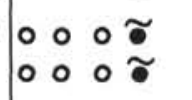 & & \\
\hline NN 4-5 & $\begin{array}{l}62-0-4-1,25 \\
62-0-4-6,125\end{array}$ & & & $\mathrm{cf}$ & $\begin{array}{r}-\quad \\
\quad \\
\\
0\end{array}$ & $\begin{array}{ll}\vdots & 0 \\
\vdots & 0\end{array}$ & & & & & \\
\hline NN 2 & $\begin{array}{l}62-0-5-2,11 \\
62-0-5-2,148 \\
62-0-5-3,25 \\
62-0-5-3,125 \\
62-0-5-4,25 \\
62-0-5-4,125 \\
62-0-5-C C\end{array}$ & & & $\bullet$ & $\begin{array}{cc}0 \bullet & 0 \\
& \\
0 & 0\end{array}$ & 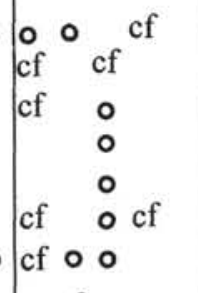 & & & & & \\
\hline $\begin{array}{l}\text { NN 1 } \\
\text { NP25 }\end{array}$ & $\begin{array}{l}62-0-6-\mathrm{CC} \\
62-0-7-\mathrm{CC}\end{array}$ & & & • & $\begin{array}{rr}0 & \bullet \\
\bullet & \mathrm{cf}\end{array}$ & cf & & & & & \\
\hline NP24 & $62-0-8-\mathrm{CC}$ & $\mathrm{cf}$ & $\widetilde{\tau}$ & $\tau$ & $\bullet$ & & & & & & \\
\hline
\end{tabular}


Some redundancy exists with respect to stratigraphic information, as such information is presented in the range charts, as well as here; but a tabulation of occurrences by species in addition to one by holes is considered worthwhile because of the convenience it offers.

The word "to" in the tabulation of species occurrences has the meaning "to and including." When section number within a core is not given, the species was found throughout the core.

\section{Catinaster calyculus}

This species is longer ranging than $C$. coalitus. Although it is not common in the upper part of its range, the long spiny, offset rays protruding beyond the margin of the central area makes it readily recognizable. Its lowest occurrence is just above the base of NN 8 and its extinction datum occurs near the top of NN 9 .

Occurrence: $62-0-3,62-1-33-3$ to $62-1-31-3,63-1-6-3$ to $63-1-5-1$, and 64-0-4-6.

\section{Catinaster coalitus}

C. coalitus has its lowest occurrence slightly below that of $C$. calyculus in Core 63-1-6, but differentiation between the two species is difficult in this part of the section because the rays of $C$. calyculus barely protrude beyond the margin of its central area in the lowest portion of its range. $C$. coalitus apparently evolves from a small discoaster resembling $D$. extensus by becoming highly concavo-convex and reducing its interray areas until they are closed. The evolution is exhibited in the upper part of Core 63-1-7. C. coalitus appears to be very resistant to recrystallization. The base of its range defines the lower boundary of NN 7. It becomes extinct at about the middle of NN 9.

Occurrence: $62-0-6,62-1-33-3$ to $62-1-32-4,63-1-6-5$ to $63-1-5-1$, and $64-0-4-6$ to $64-0-4-2$.

\section{Ceratolithus cristatus}

C. cristatus differs from the similar $C$. rugosus in being less heavily calcified. There appear to be no transitional forms between the two. C. cristatus is similar in appearance to $C$. tricorniculatus, but $C$. tricorniculatus is not birefringent and their ranges do not appear to overlap. C. cristatus occurs sporadically from NN 16 through NN 21 in Holes 62, 63, and 64, but it is very rare in NN 16; and, the base of its range could not be accurately determined.

\section{Ceratolithus rugosus}

The ranges of $C$. rugosus and $C$. cristatus overlap but there appear to be no transitional forms between the two. The lowest appearance of $C$. rugosus marks the base of $\mathrm{NN} 13$ and approximates the Mio-Pliocene boundary.
Occurrence: $62-0-1,62-1-13-4$ to $62-1-5,63-1-3,63-2-$ 3 , and 64-0-2.

\section{Ceratolithus tricorniculatus}

Transitional forms between C. rugosus and C. tricorniculatus occur in the range of overlap between the two species suggesting that $C$. rugosus is a direct descendant of $C$. tricorniculatus. Specimens similar in morphology to $C$. rugosus, but having almost no birefringence, occur within this interval. The highest occurrence of $C$. tricorniculatus defines the top of NN 14, but the sparsity of this species in the samples studied made accurate determination of its highest occurrence imprecise.

Occurrence: Sporadically in Holes 62, 63 and 64 as low as NN 8.

\section{Coccolithus eopelagicus}

This easily-recognized species appears to be identical to C. pelagicus except for its larger size. Forms transitional in size between the two were found in the range of their overlap. The range of $C$. eopelagicus was not plotted, but it appears to become extinct within NN 1 .

\section{Coccolithus pelagicus}

C. pelagicus and closely allied forms range through the Neogene and apparently exhibit changes which could prove stratigraphically useful. However, all attempts to subdivide it thus far have not met with success. The species becomes restricted to cold water late in the Neogene.

\section{Coccolithus tenuistriatus}

Reticulofenestra umbilica of Eocene age and R. pseudoumbilica of Pliocene age both closely resemble $C$. tenuistriatus but the three do not have overlapping ranges. Many smaller species somewhat resemble $C$. tenuistriatus and are easily confused with it when it is not present in a sample. The basal occurrence of this species is within NN 6 and its highest occurrence is within NN 10.

Occurrence: $62-0-3,62-1-3,62-1-38-1$ to $62-1-29-3$, $63-1-8-4$ to $63-1-5-1$, and $64-0-4$.

\section{Cyclococcolithus leptoporus}

This species is common to abundant throughout the Neogene and appears to be of little stratigraphic value for this part of the section. It was noted in virtually all Neogene samples studied but was not recorded in the range charts.

\section{Dictyococcites dictyodus}

D. dictyodus has its last occurrence in NN 1 and the distinctiveness and wide distribution of the species renders its extinction datum very useful. However, this datum could not be accurately determined because of limited recovery for this part of the column. 


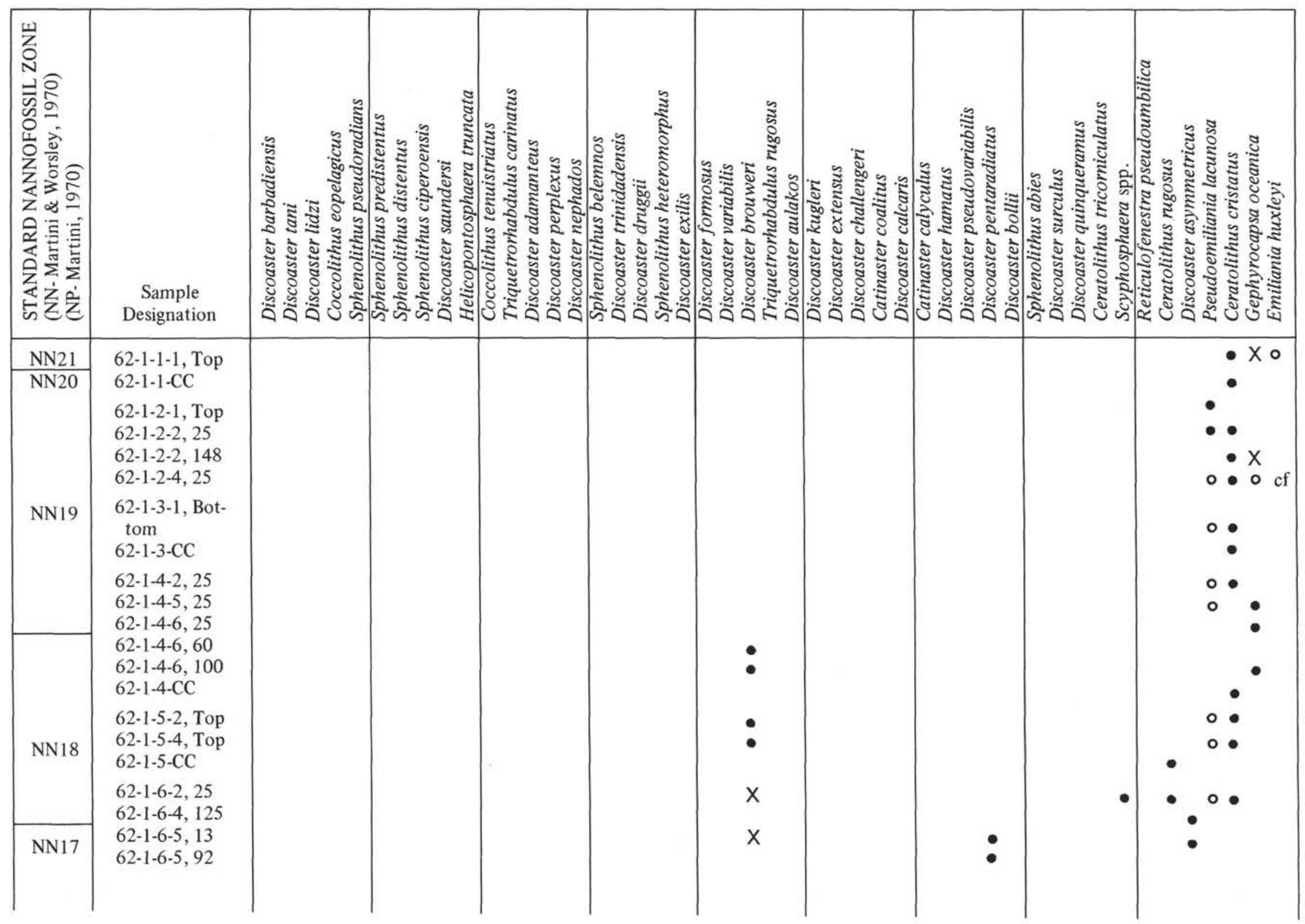




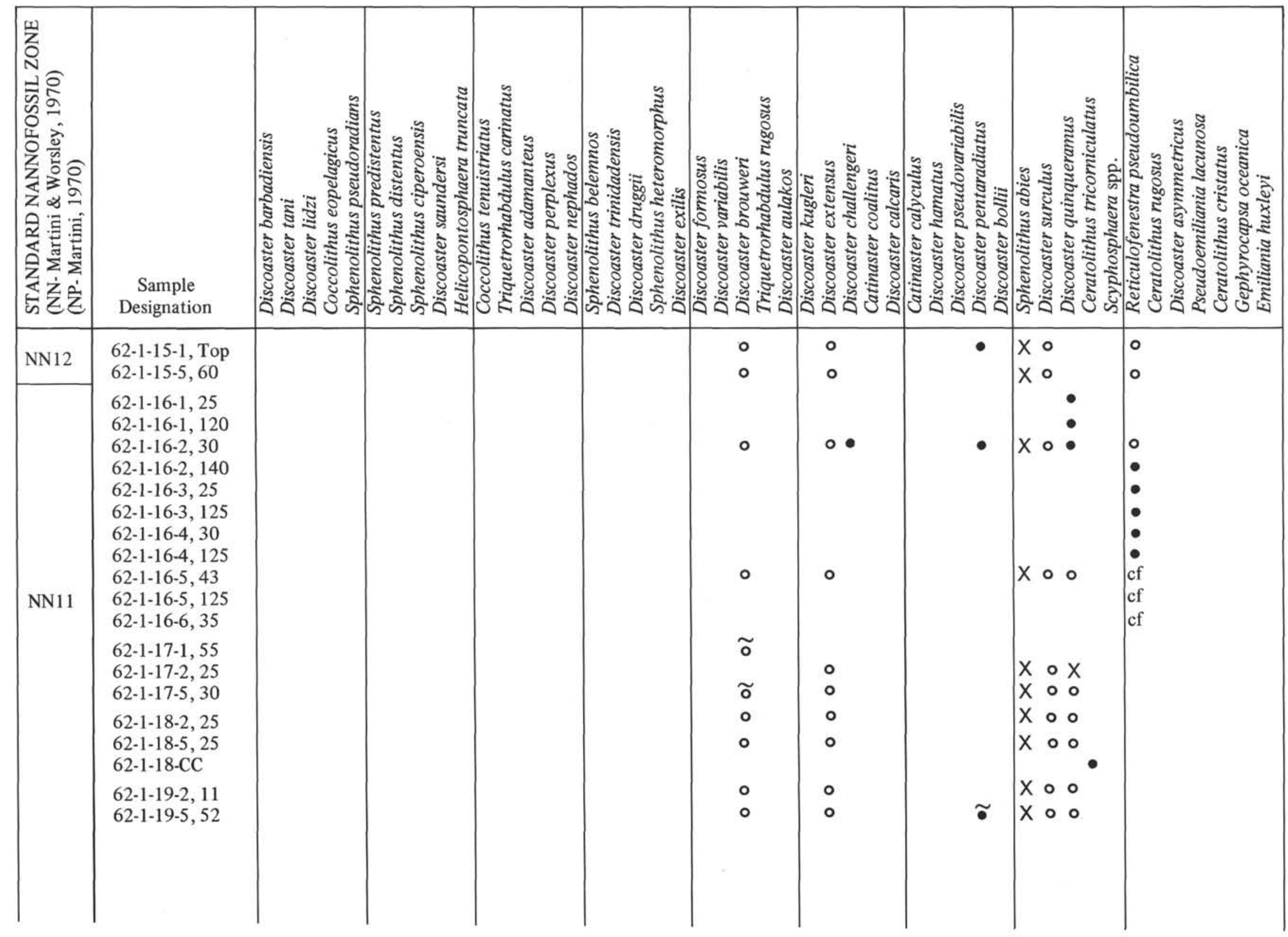




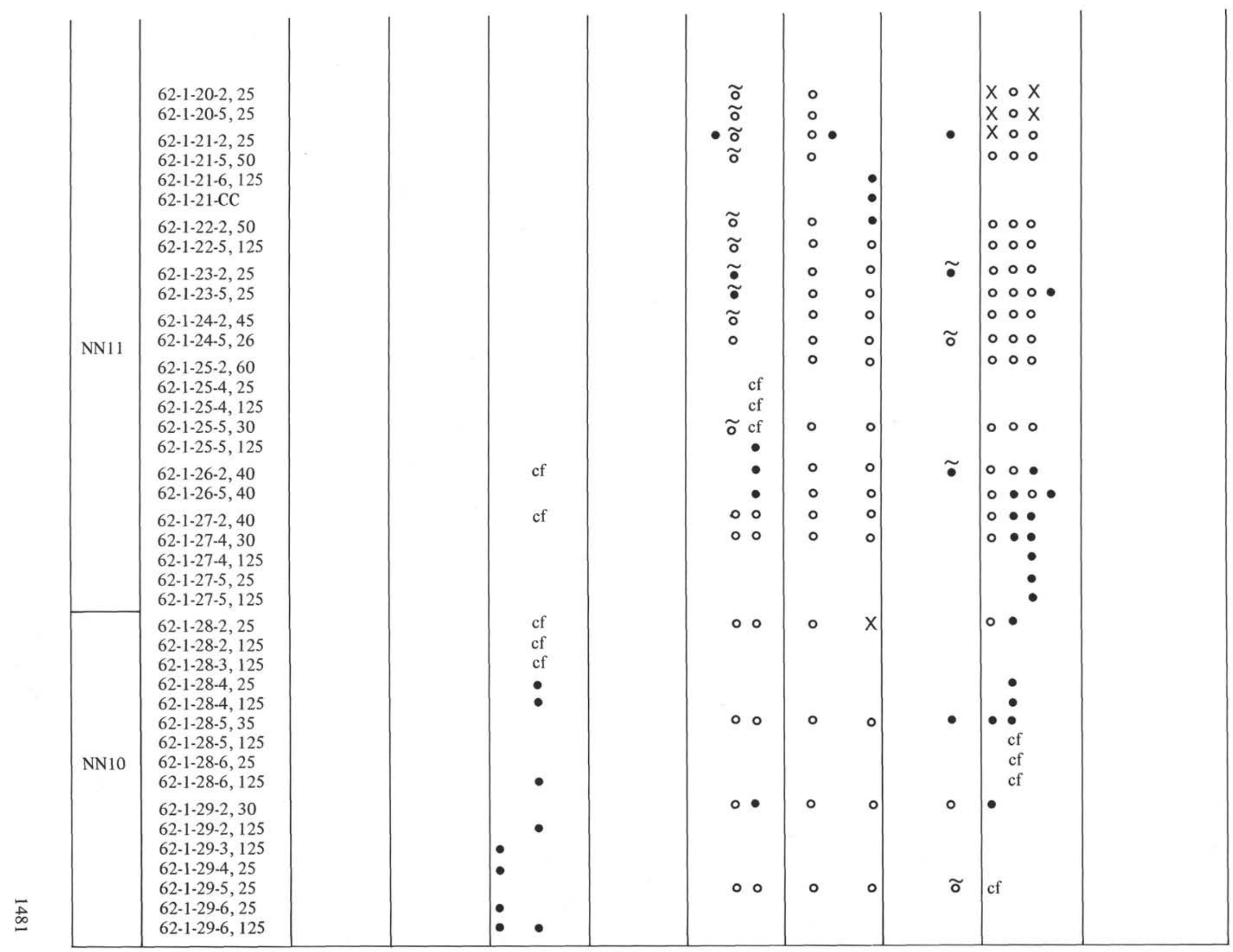




\begin{tabular}{|c|c|c|c|c|c|c|c|c|c|c|}
\hline 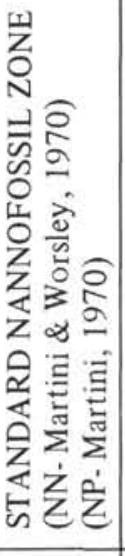 & $\begin{array}{c}\text { Sample } \\
\text { Designation }\end{array}$ & 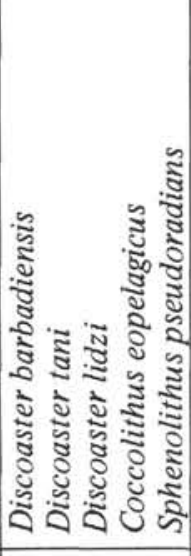 & 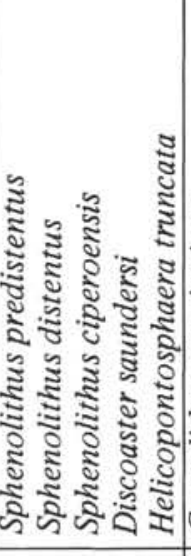 & 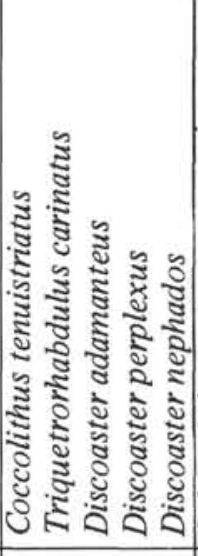 & 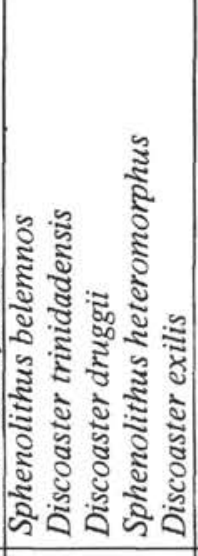 & 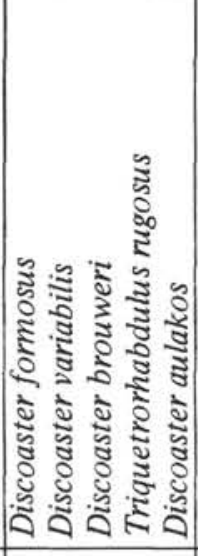 & 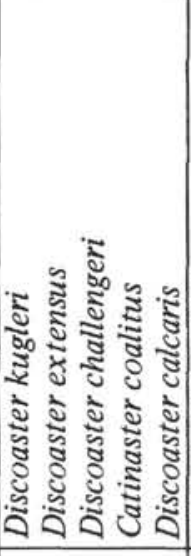 & 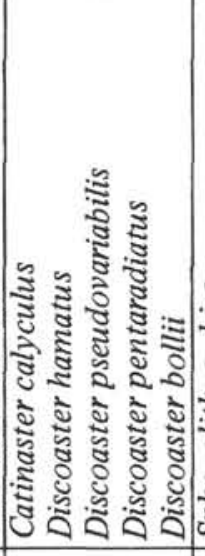 & 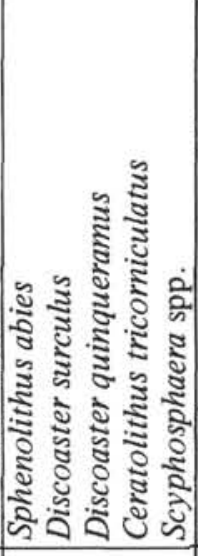 & 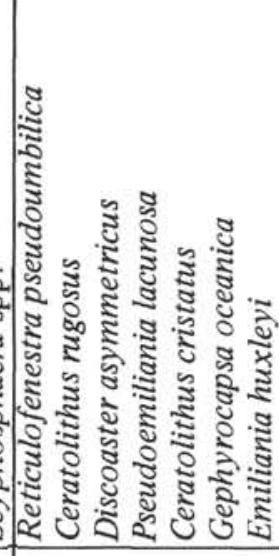 \\
\hline NN10 & $\begin{array}{l}62-1-30-1,25 \\
62-1-30-2,25 \\
62-1-30-3,25 \\
62-1-30-3,125 \\
62-1-30-4,25 \\
62-1-30-5,25 \\
62-1-30-C C\end{array}$ & & & $\begin{array}{l}\bullet \\
\bullet \\
\bullet\end{array}$ & & $\begin{array}{l}\text { ธ。 } \\
\text { ธ。 }\end{array}$ & $\begin{array}{ll}\circ & 0 \\
0 \mathrm{cf} & 0\end{array}$ & $\begin{array}{c}\widetilde{\sigma} \\
\approx\end{array}$ & cf & \\
\hline NN 9 & $\begin{array}{l}62-1-31-1,25 \\
62-1-31-1,125 \\
62-1-31-2,25 \\
62-1-31-3,25 \\
62-1-31-3,125 \\
62-1-31-4,25 \\
62-1-31-5,25 \\
62-1-31-6,125 \\
62-1-31-C C \\
62-1-32-1,125 \\
62-1-32-2,25 \\
62-1-32-2,125 \\
62-1-32-3,25 \\
62-1-32-3,125 \\
62-1-32-4,25 \\
62-1-32-4,125\end{array}$ & & & $\begin{array}{ll}\bullet & \\
& \bullet \\
& \bullet \\
& \circ\end{array}$ & & $\begin{array}{l}\text { cf } \approx \circ \\
\text { cf } \approx \circ \\
\text { cf } \approx\end{array}$ & \begin{tabular}{cc|}
$0 \mathrm{cf}$ & 0 \\
0 & 0 \\
0 & 0 \\
0 & $\bullet$ \\
$\bullet$
\end{tabular} & 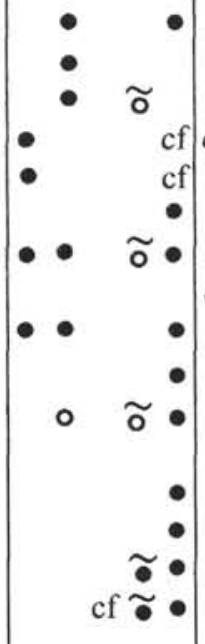 & cf & \\
\hline
\end{tabular}




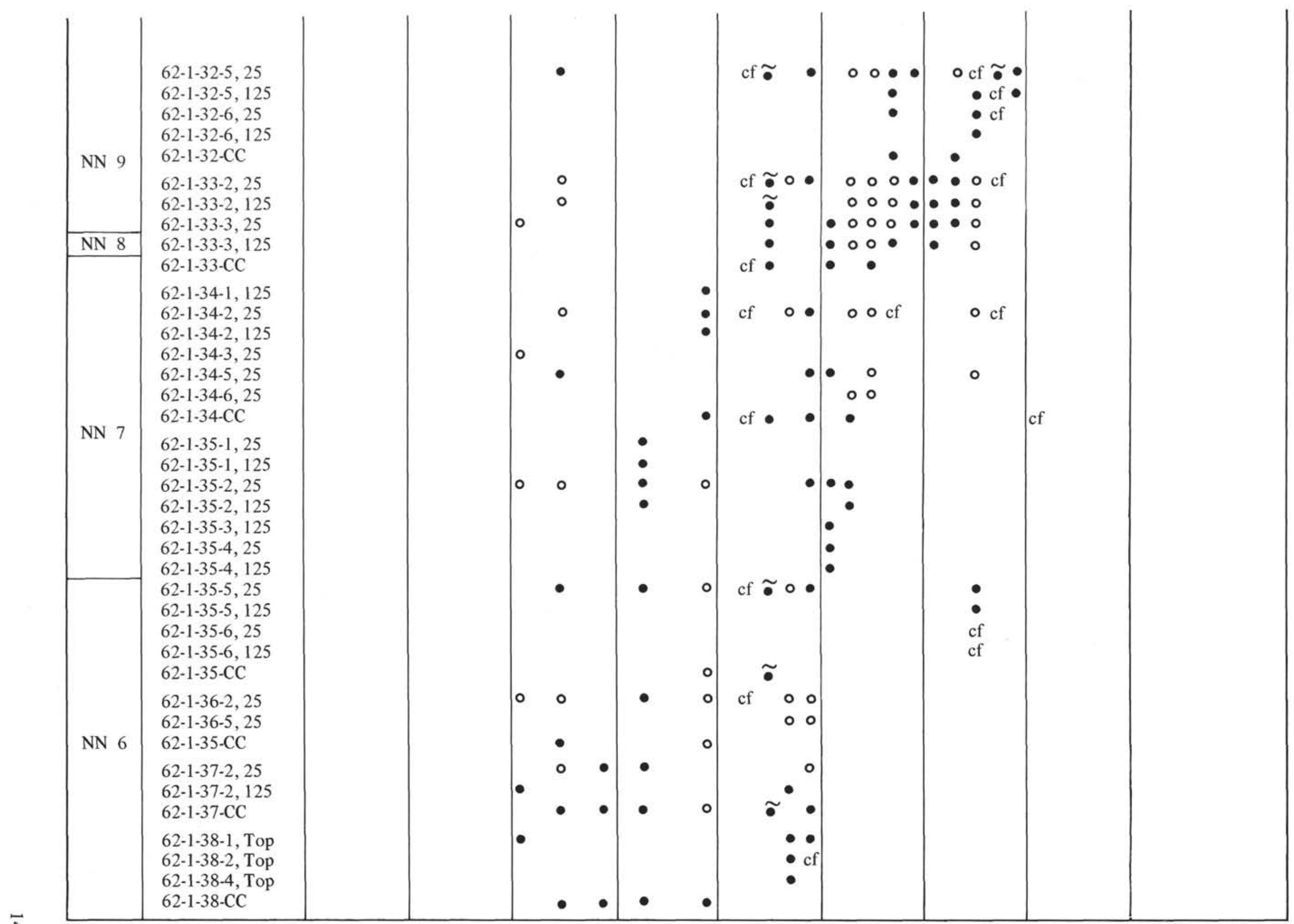




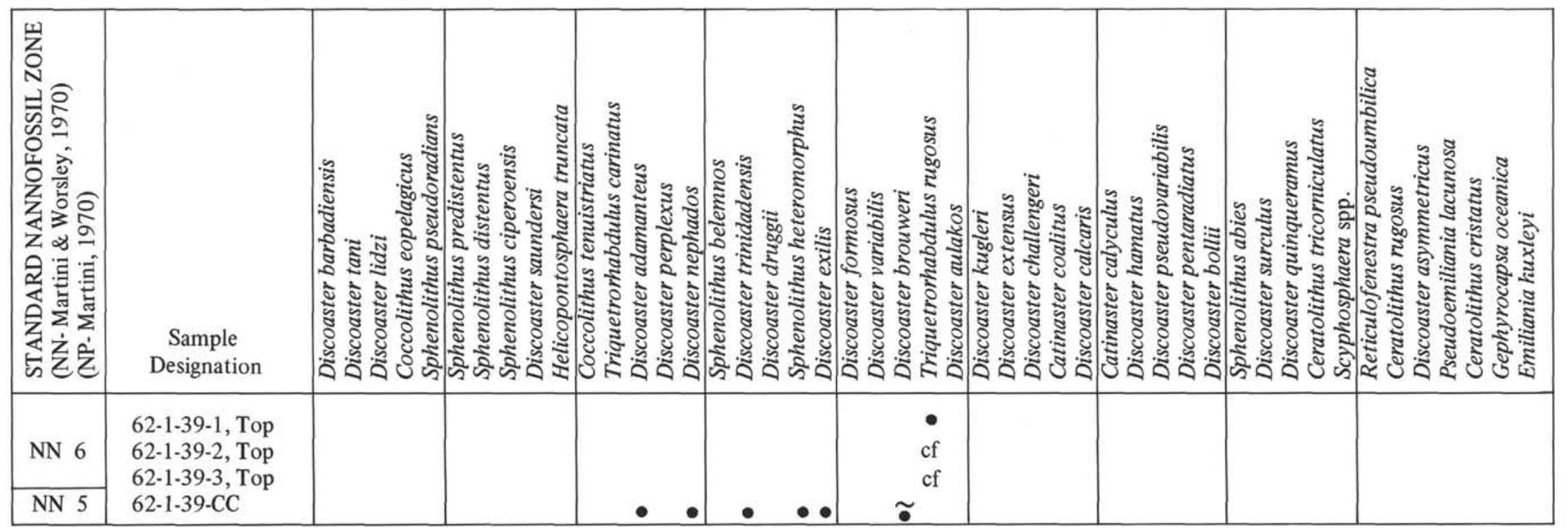




\section{Discoaster adamanteus}

Included within this taxon are all relatively small sixrayed asteroliths with straight-sided, pointed arms without terminal bifurcations. Heavily calcified specimens are hexagonal in outline. Among the names given to variants within this group are $D$. obtusus and $D$. lautus. Discoasters of this shape are common in the late Paleogene and become extinct near the top of NN 10.

Occurrence: $62-0-8$ to $62-0-3,62-1-39$ to $62-1-28-4$, 63-0-5 to $63-0-3,63-1-14$ to $63-1-5,64-0-7$ to $64-0-4$, and $64-1-8$ to $64-1-1$.

\section{Discoaster asymmetricus}

The lowest occurrence of this species defines the base of NN 14. It is very distinctive and easily recognized in well-preserved assemblages, but can easily be confused with partially dissolved specimens of $D$. pentaradiatus in sediments deposited near compensation level. $D$. asymmetricus becomes extinct in the lower part of NN 18.

Occurrence: $62-0-1,62-1-11-1$ to $62-1-6-4,63-2-3$, and 64-0-2.

\section{Discoaster aulakos}

To this species are referred all five- and six-rayed asteroliths of the $D$. deflandrei group whose ray tip bifurcations have been filled in with calcite to produce " $T$ " or "club" shaped terminations. It is probable that specimens of $D$. extensus and $D$. variabilis have been misidentified as $D$. aulakos in poorly preserved assemblages. The lowest occurrence of D. aulakos is NN 6 and its highest occurrence is in NN 9.

Occurrence: $62-0-3,62-1-38-1$ to $62-0-32-2,63-0-3-1$, $63-1-8$ to $63-1-6-4$, and $64-0-5$ to $64-0-6$.

\section{Discoaster barbadiensis}

Well-preserved specimens of $D$. barbadiensis were encountered in Upper Eocene strata in otherwise poorly preserved assemblages, indicating that this species is extremely resistant to solution and recrystallization. It is an excellent calcareous guide fossil for deep water pelagic sediments.

Occurrence: $64-1-9,64-1-10,65-0-15,65-0-16,65-1-2$, and 65-1-3.

\section{Discoaster bollii}

The extremely short range of this species renders it one of the most useful mid to late Miocene guide fossils available. Its lowest occurrence is in the middle of NN 9 and it becomes extinct just above the base of NN 10 . Many superficially similar forms exist in the lower and middle Miocene, but none have the distinctive combination of a very prominent central knob and ray tip bifurcations.

Occurrence: $62-1-32-5$ to $62-1-30$-core catcher, and $63-1-5$.

\section{Discoaster brouweri}

$D$. brouweri is the general name given to all three- to six-rayed asteroliths with long delicate arms without terminal bifurcations. The taxon is used on the range charts to refer to specimens which cannot be placed into one of the many species into which this group has been divided. The extinction of $D$. brouweri delineates the top of NN 18.

Occurrence: Common to abundant in sediments ranging in age from NN 6 to the top of NN 18.

\section{Discoaster calcaris}

This distinctive member of the $D$. brouweri group has its lowest occurrence just above that of $D$. hamatus and the two resemble each other in all respects except that $D$. calcaris has six rays whereas $D$. hamatus has five. The range of $D$. hamatus defines NN 9, but $D$. calcaris persists upward into NN 11 and its extinction datum is useful in dividing this long zone.

Occurrence: $62-0-3$ to $63-0-1,62-1-34-5$ to $62-1-8-5$, $21-6,63-0-2,63-1-6-2$ to $63-1-5-1$, and $64-0-4-3$ to 64-0-3-1.

\section{Discoaster challengeri}

$D$. challengeri is a member of the $D$. extensus- $D$. variabilis group characterized by its large size, long parallelsided rays and stellate central knob. Its range does not significantly differ from that of $D$. extensus.

Occurrence: $62-0-3$ to $63-0-1,62-1-34-5$ to $62-1-8-5$, $63-0-2,63-1-7-3$ to $63-1-5$, and $64-0-4$ to $64-0-2$.

\section{Discoaster druggi}

D. druggii whose lowest occurrence defines the base of NN 2, persists into NN 3. It is therefore restricted to a short interval in the Lower Miocene. There are many Miocene forms which resemble it almost exactly, but they are only a fraction of the size of this extremely large asterolith.

Occurrence: $62-0-5-6$ to $62-0-5-1,63-0-4,63-1-14-6$ to 63-1-14-3, and 64-0-7-3 to 64-0-6-6.

\section{Discoaster exilis}

The level of the lowest occurrence of $D$. exilis approximates the level of highest occurrence of Helicopontosphaera ampliaperta, which apparently does not occur in the western Pacific, and has provisionally been used to approximate the base of NN 5 . The highest occurrence of $D$. exilis is within the upper part of NN 7 .

Occurrence: $62-1-39$ to $62-1-34-1,63-0-3,63-1-13-6$ to 63-1-7-3, 64-0-5, and 64-1-2 to 64-1-1.

\section{Discoaster extensus}

All five- and six-rayed asteroliths having nearly parallelsided rays terminating in wide angle bifurcations and not possessing a central knob have been referred to $D$. extensus. In poorly preserved samples, species such as 
TABLE 4

Distribution of Calcareous Nannofossils in Cores from Hole 63-0

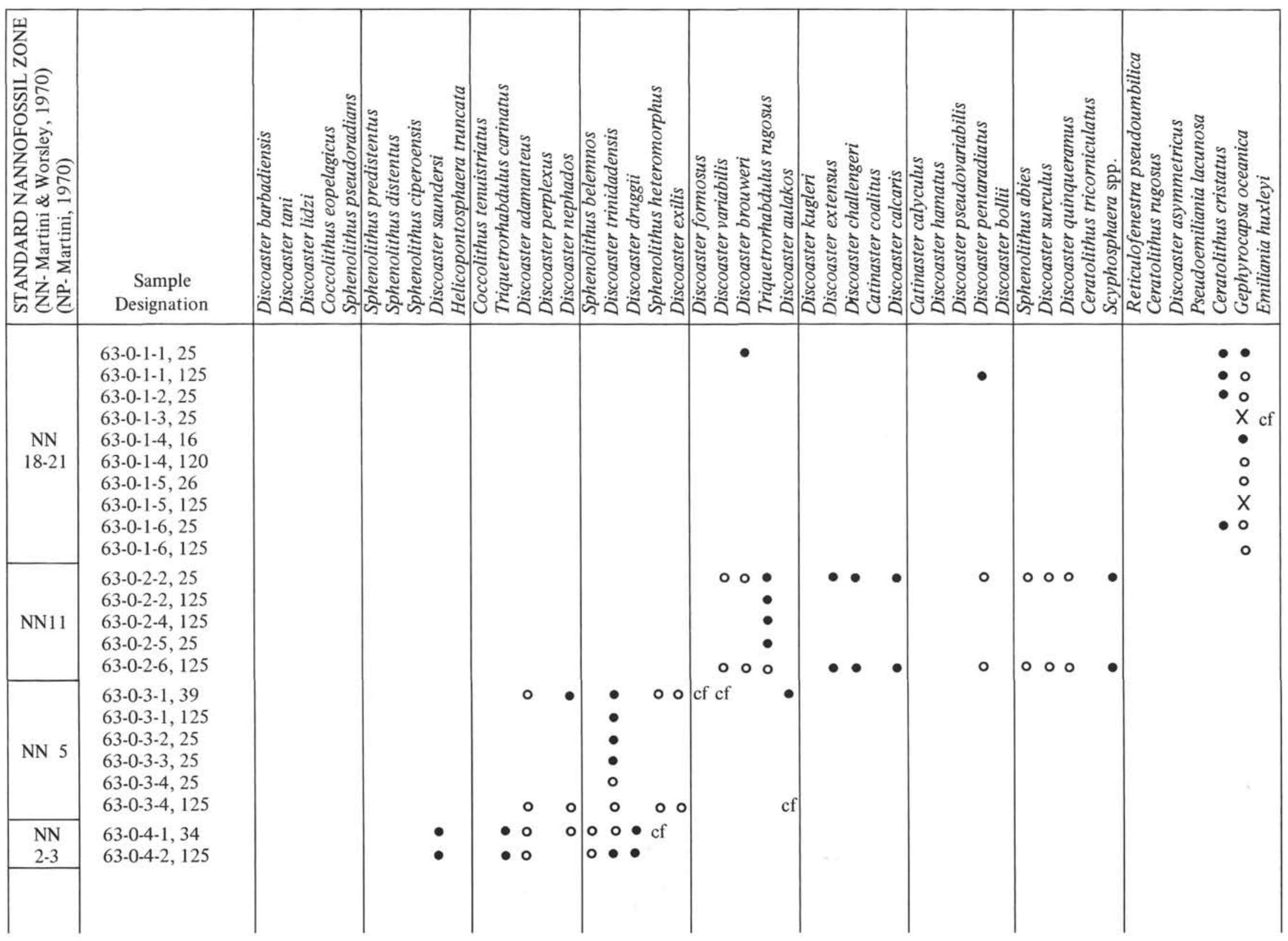



63-0-5-CC

63-0-6-1, 24 63-0-6-6, 125

63-0-7-1, 35

63-0-7-6, 125

63-0-8-1, 60

63-0-8-3, 125

63-0-9-1, 24

63-0-9-6, 125 
TABLE 5

Distribution of Calcareous Nannofossils in Cores from Hole 63-1

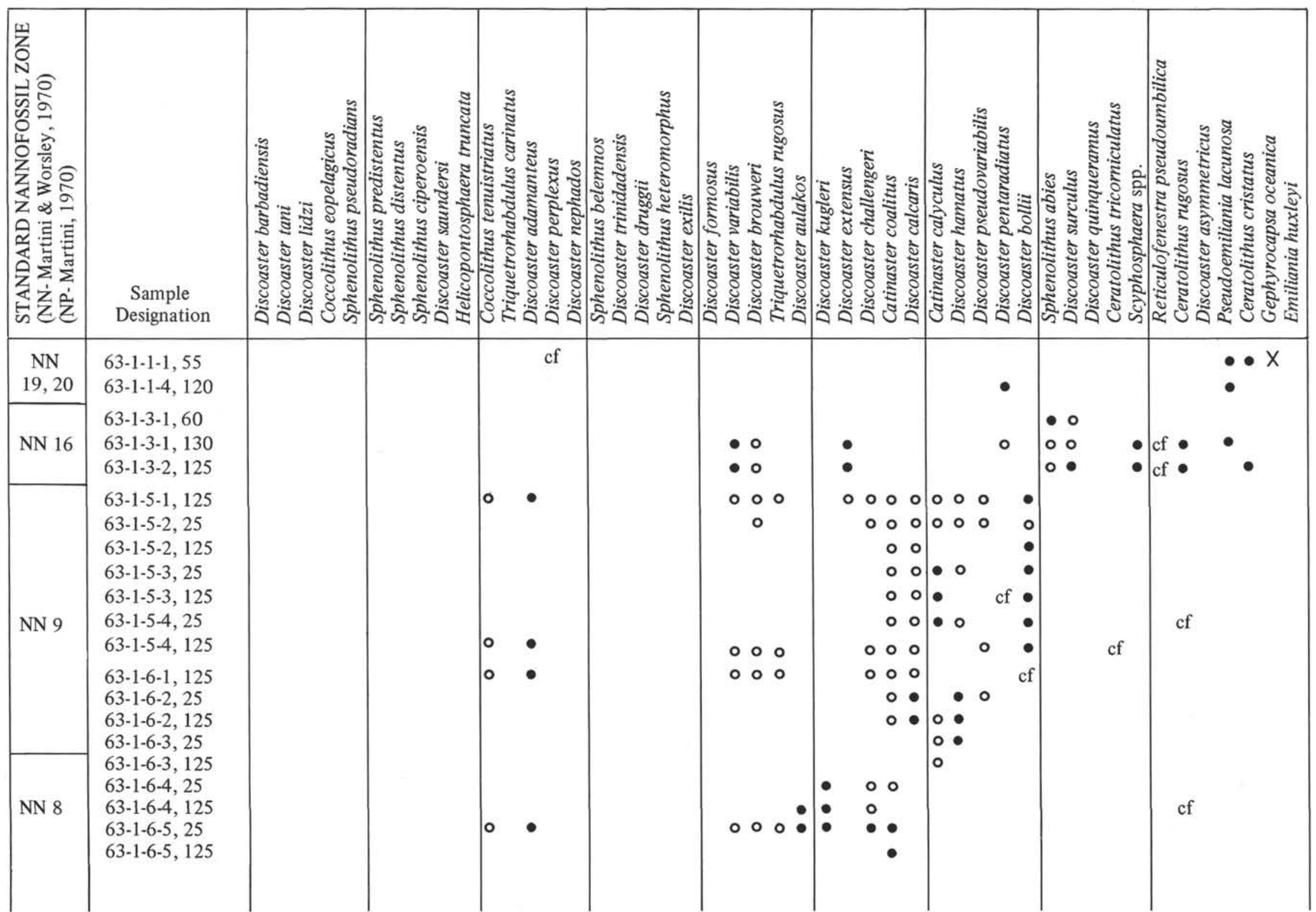




\begin{tabular}{|c|c|c|c|c|c|c|c|c|c|c|c|}
\hline 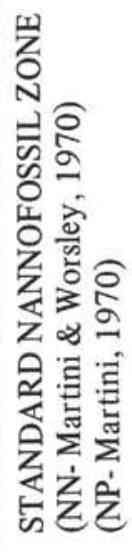 & $\begin{array}{c}\text { Sample } \\
\text { Designation }\end{array}$ & 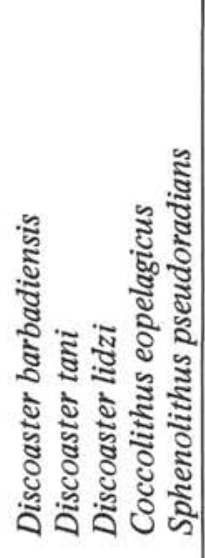 & 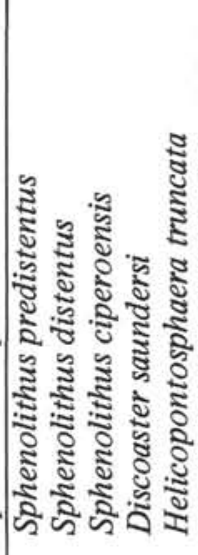 & 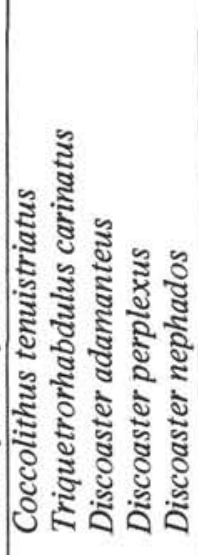 & 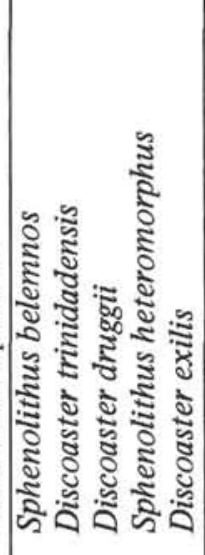 & 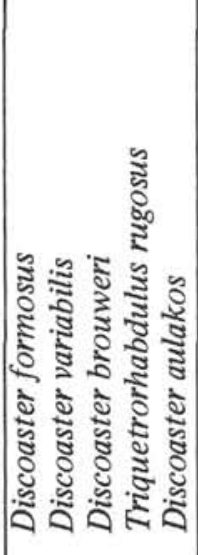 & 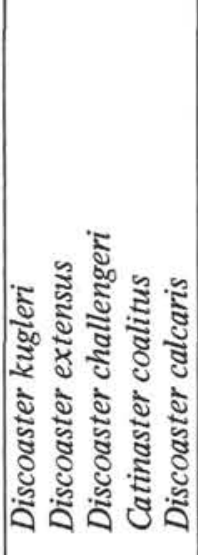 & 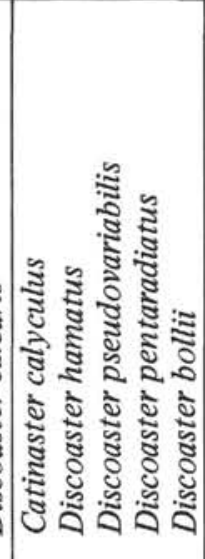 & 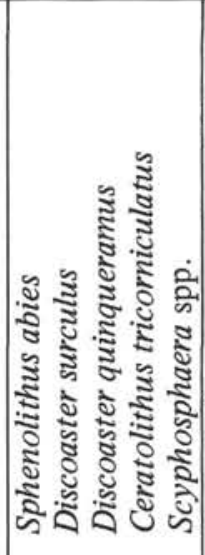 & 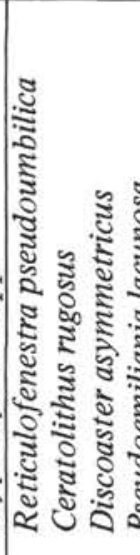 & 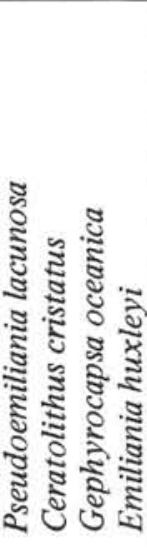 \\
\hline $\begin{array}{c}\mathrm{NN} \\
20,21\end{array}$ & \multirow{6}{*}{$\begin{array}{l}63-2-1-1, \text { Top } \\
63-2-1-1,125 \\
63-2-1-2,125 \\
63-2-1-3,125 \\
63-2-1-4,125 \\
63-2-1-5,125 \\
63-2-2-1,125 \\
63-2-2-2,100 \\
63-2-2-3,125 \\
63-2-2-4,125 \\
63-2-2-6,25 \\
63-2-2-6,125 \\
63-2-3-1,125 \\
63-2-3-2,125 \\
63-2-3-3,125 \\
63-2-3-4,25\end{array}$} & & & & & \multirow{6}{*}{$\begin{array}{ll} & \bullet \\
& \\
& x \\
& 0 \\
& 0 \\
& 0 \\
& 0 \\
0 & 0 \\
0 & 0 \\
0 & 0 \\
0 & 0 \\
0 & 0 \\
0 & 0\end{array}$} & & \multirow[b]{6}{*}{$\begin{array}{l}\circ \\
\circ \\
\circ \\
\circ\end{array}$} & \multirow[b]{6}{*}{$\begin{array}{ll}x & 0 \\
x & 0 \\
x & 0 \\
x & 0\end{array}$} & \multirow{6}{*}{\multicolumn{2}{|c|}{$\begin{array}{ll}\text { cf } \quad \begin{array}{l}\bullet \\
\end{array} & \circ \\
& \stackrel{\circ}{c f}\end{array}$}} \\
\hline NN 19 & & & & & & & & & & & \\
\hline NN 18 & & & & & & & & & & & \\
\hline NN 17 & & & & & & & & & & & \\
\hline $\begin{array}{c}\text { NN } \\
14,15\end{array}$ & & & & & & & & & & & \\
\hline & & & & & & & & & & & \\
\hline
\end{tabular}


D. challengeri and D. variabilis have probably been referred to as $D$. extensus. The species ranges from the top of NN 6 as high as NN 17.

\section{Discoaster formosus}

See new species section.

\section{Discoaster hamatus}

The range of this species is the increment encompassed by NN 9 . The pronounced offset and downcurving of the ray tips of this five-armed asterolith permit identification even in poorly preserved assemblages.

Occurrence: $62-0-3,62-1-33-3$ to $62-1-31-1,63-1-6-3$ to $63-1-5-1$, and 64-0-4.

\section{Discoaster kugleri}

The lowest occurrence of this species defines the base of NN 7. The species persists into NN 8. D. kugleri evolves from a stock of nondescript six-rayed asteroliths characterized by a large central area and blunt tipped arms. These generalized forms persist above the highest occurrence of $D$. kugleri but all appear restricted to the Middle Miocene.

Occurrence: $62-1-35-4$ to $62-1-33-3$ and $63-1-7-4$ to 63-1-6-4.

\section{Discoaster nephados}

D. nephados was found to have a slightly different range than $D$. trinidadensis; however, both are restricted to the latest Oligocene and early Miocene. D. nephados is easily confused with specimens of many other species in poorly preserved samples because secondary calcification tends to produce stubby parallel-sided rays on many species of asteroliths.

Occurrence: $62-0-6$ to $62-0-4,62-1-39$ to $62-0-37-2$, 63-0-5-2 to $63-0-3-1,63-1-14$ to $63-1-8-3,64-0-8-3$ to $64-0-5-1$, and $64-1-7-4$ to $64-1-1-1$.

\section{Discoaster pentaradiatus}

These delicate five-rayed asteroliths are among the easiest discoasters to recognize when well-preserved. When partially dissolved or recrystallized, the ray tip bifurcations are usually not preserved and specimens appear similar to members of the $D$. brouweri group. D. pentaradiatus has its first occurrence in NN 9, but poor preservation made its recognition difficult throughout much of the Upper Miocene and Pliocene. Its extinction datum defines the upper limit of NN 17.

Rare six-rayed specimens having construction almost identical to that of $D$. pentaradiatus were observed in Cores 2 and 3 of Hole 63-2.

Occurrence: $62-0-3$ to $62-0-1,62-1-32-5$ to $62-1-6-5$, 63-0-2, 63-1-5? to 63-1-3, and 64-0-3 to 64-0-2.

\section{Discoaster perplexus}

This unusual species has a very unpredictable distribution in the western Pacific. It is probably still living today but the level of its highest occurrence varies with location, suggesting that this species has been subject to some type of environmental restriction throughout much of the Neogene. A study of its stratigraphic distribution might lead to its use as an environmental indicator.

Occurrence: As low or lower than NN 2. Instances in which it was found are shown in the range charts.

\section{Discoaster pseudovariabilis}

See the section on discussion of new species.

\section{Discoaster quinqueramus}

The range of this species represents NN 11. The zone represents a long period of time which is difficult to subdivide. Triquetrorhabdulus rugosus and Discoaster calcaris become extinct within this zone and are of help in subdivision.

Occurrence: $62-0-2,62-1-27-5$ to $62-1-16-1,63-0-2$, and 64-0-3.

\section{Discoaster saundersi}

This distinctive species within the $D$. deflandrei group ranges from Late Oligocene to NN 2. It becomes extinct just below the level of the highest Triquetrorhabdulus carinatus.

Occurrence: $62-0-8$ to $62-0-5,63-0-10$ to $63-0-4,63-1$ 14-6, 64-0-10 to 64-0-6-6, and 64-1-8.

\section{Discoaster surculus}

This easily recognized species has its lowest occurrence in the upper part of NN 10, and its uppermost occurrence is used to define the top of NN 16. Some forms of $D$. pseudovariabilis (n. sp.) resemble $D$. surculus, but the ranges of the two do not overlap.

Occurrence: $62-0-2$ to $62-0-1,62-1-28-5$ to $62-1-7-2$, 63-0-2, 63-1-3, and $64-0-3$ to $64-0-2$.

\section{Discoaster tani}

Large five-rayed asteroliths with parallel-sided arms from the Eocene and Oligocene have been referred to this species. Extensive recrystallization within samples studied renders division into subspecies impossible.

Occurrence: $63-0-10$ to $63-0-6$ and $64-1-10$ to $64-1-9$.

\section{Discoaster trinidadensis}

$D$. trinidadensis is a variant within the $D$. deflandrei group characterized by pentagonal-shaped rays. Its range is similar to that of $D$. nephados, but results of this study indicate that the ranges of the two are not precisely the same. The lowest occurrence of $D$. trinidadensis is in the Paleogene and its highest in NN 7. 


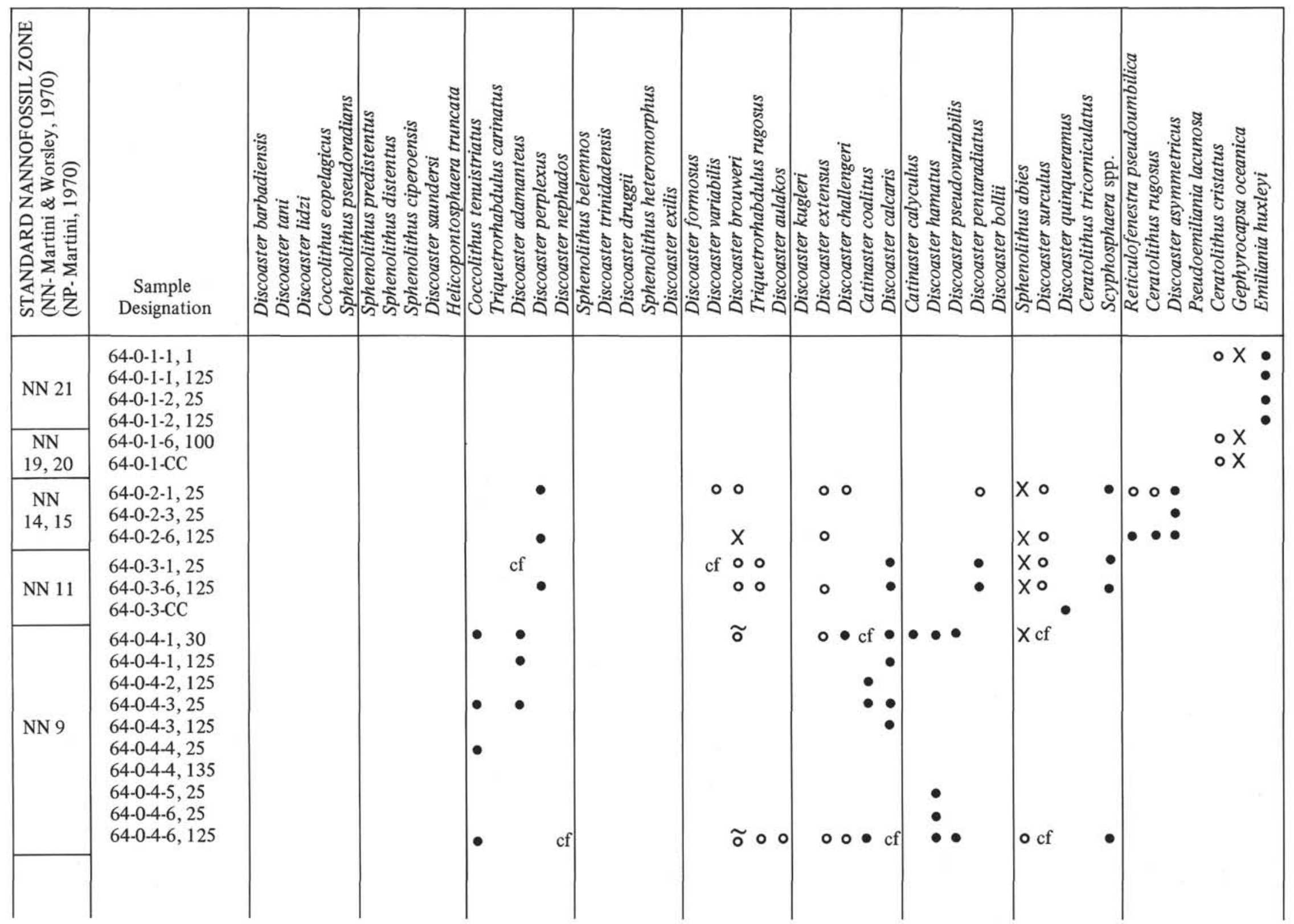




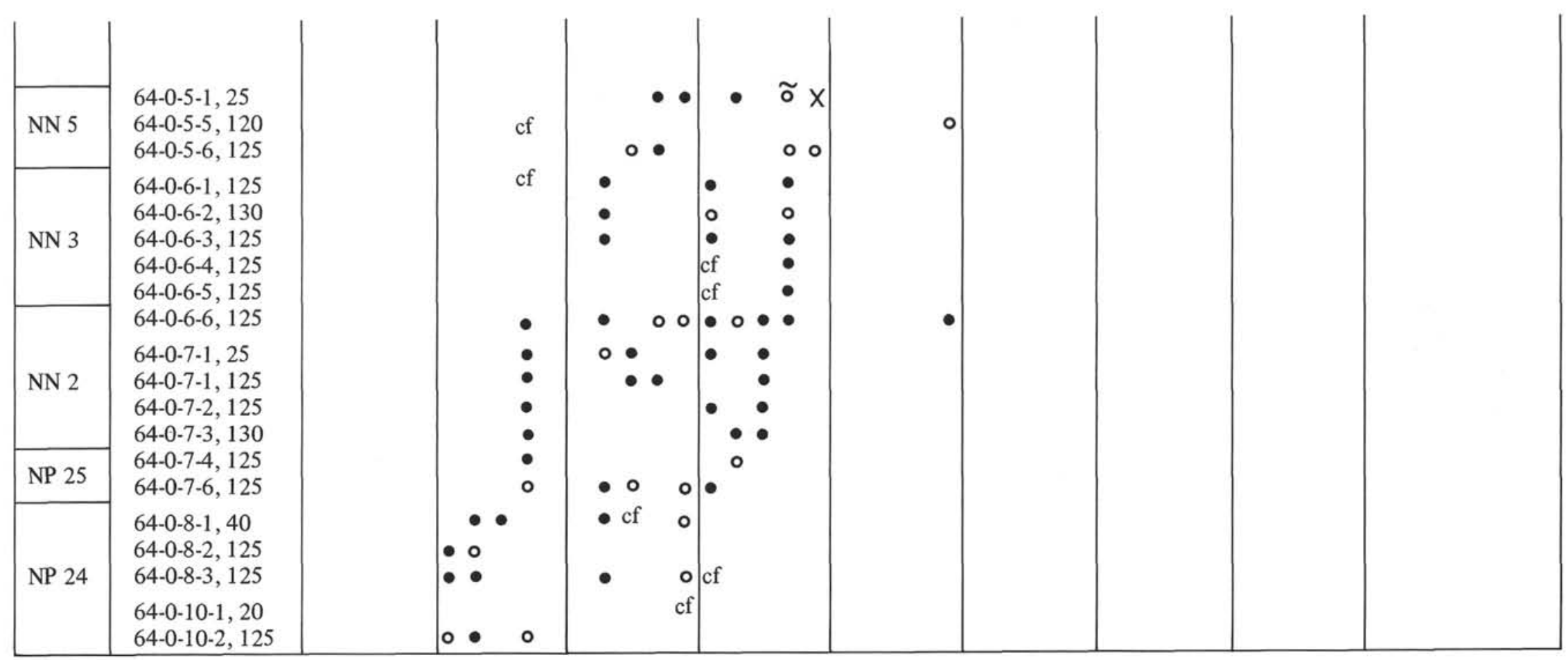




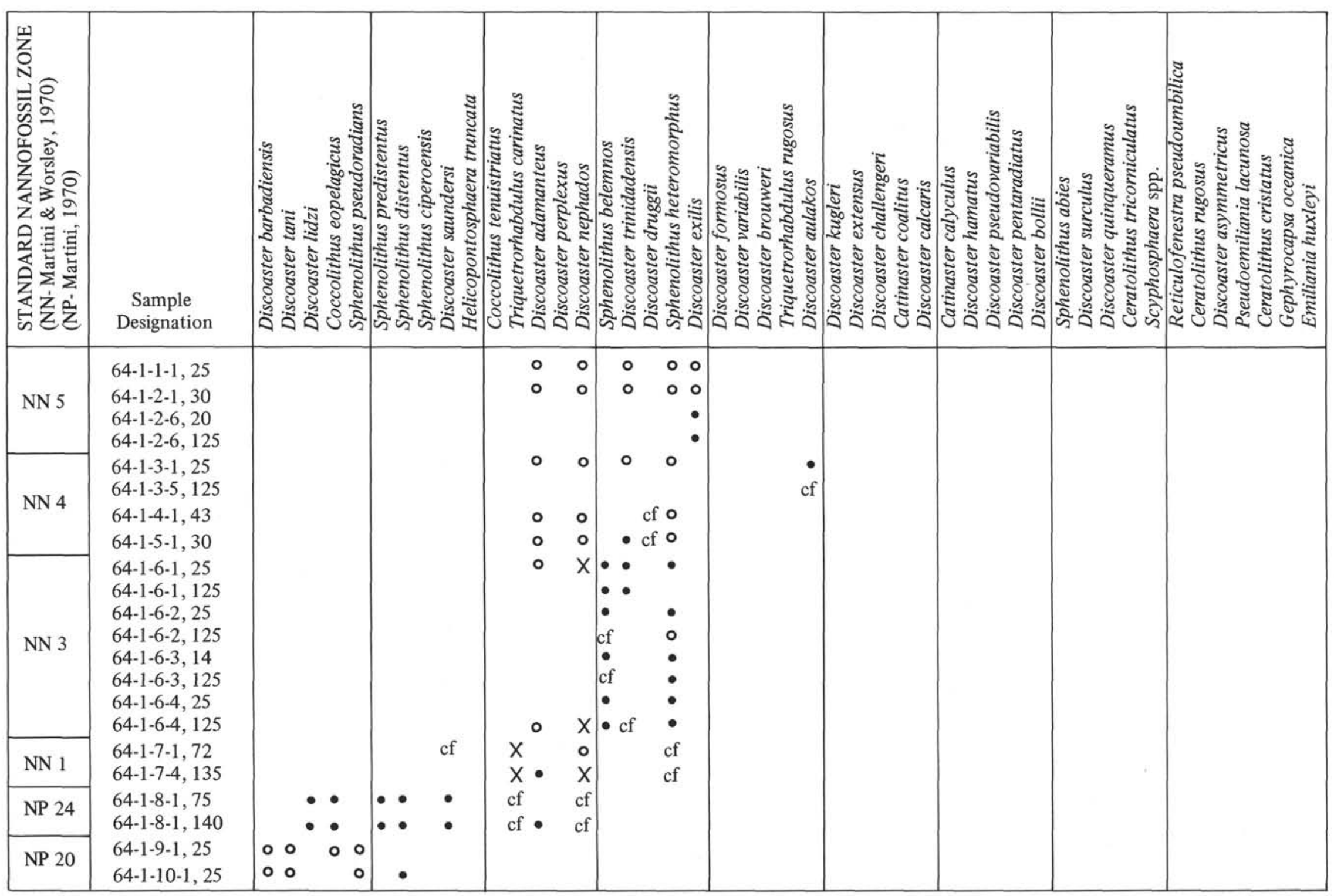


Occurrence: $62-0-5$ to $62-0-4,62-1-39$ to $62-1-35-1$, 63-0-4 to $63-0-3,63-1-14$ to $63-1-7-4,64-0-7$ to 64-0-5, and 64-1-6-1 to 64-1-1-1.

\section{Discoaster variabilis}

D. variabilis is a member of the D. extensus group possessing an elaborate central knob. Its lowest occurrence is probably in NN 5, but poor preservation of the species in this part of the section does not permit precise identification and it was probably referred to as $D$. extensus. Its highest occurrence is in NN 17 or 18. It is apparently absent in parts of the Neogene, but this may be because it was identified as $D$. extensus.

\section{Emiliania huxleyi}

This upper Pleistocene species is recognizable in the light microscope with difficulty, as it is only about 2 microns in diameter. Cross-polarized light and an oil immersion objective lens are required for its identification. A blue or green filter is helpful for obtaining higher resolution by shortening wavelength and eliminating chromatic aberration. The species is characterized by " $T$ "-shaped shield elements and a central grille. The calcite of the "T"-shaped elements is weakly birefringent, thus permitting their recognition; but, the central grille remains dark between crossed nicols because it is very thin. This species is probably restricted to the Wisconsinian. Its basal occurrence delineates the lower limit of NN 21, the highest Neogene nannofossil zone. Occurrence: $62-1-1-1$ and 64-0-1-2 to 64-0-1-1.

\section{Gephyrocapsa oceanica}

Several species of Gephyrocapsa exist but are distinguished from each other only with difficulty in the light microscope. There appears to be a complete suite of transitional forms between these, thereby rendering determination of highest and lowest occurrences even more difficult. For these reasons, all species of Gephyrocapsa are herein referred to as $G$. oceanica. The genus is relatively easy to recognize in cross-polarized light because it possesses a robust crossbar inclined at an angle to the minor axis. It appears extremely resistant to solution; but, when partially dissolved, smaller specimens having lost their crossbars may resemble Emiliana huxleyi because solution progresses at a faster rate along the sutures leaving "I"-shaped elements. These solutional features differ, however, from those of $E$. huxleyi in having pointed terminations rather than " $T$ "-shaped ones. The genus has its lowest occurrence in NN 18 and is a major constituent of the present phytoplankton population.

Occurrence: $62-1-4-6$ to $62-1-1-1,63-0-1,63-1-1-1$, and 64-0-1.

\section{Helicopontosphaera kamptneri}

This large, easily identified species is usually common in all samples of Neogene age and ranges into the
Paleogene. Its occurrence is not plotted in the range charts.

\section{Helicopontosphaera truncata}

This species is rare in sediments in the western Pacific. One specimen was recorded from 63-0-5-2 (125 to 126 centimeters). Its highest occurrence defines the base of NN 1 (see discussion of NP Zone 25).

\section{Pseudoemiliania lacunosa}

Small specimens of this distinctive species make their first appearance in NN 16. It becomes progressively larger and more abundant, but rapidly declines in numbers in the lower Pleistocene and becomes extinct. Both circular and elliptical varieties exist but an attempt at independent determination of the ranges of each did not result in stratigraphic separation of the two. The extinction datum of the species marks the top of NN 18 . Occurrence: $62-0-1,62-1-8-6$ to $62-1-2-1$, and 63-1-3-1.

\section{Reticulofenestra pseudoumbilica}

This relatively large species is generally easy to identify among the small species which comprise Pliocene and Upper Miocene nannofloras. See the discussion of Coccolithus tenuistriatus for stratigraphic interpretation of homeomorphy of $R$. pseudoumbilica and other species.

Occurrence: $62-0-1,62-1-16-4$ to $62-1-9-$ core catcher, and 64-0-2.

\section{Scyphosphaera spp.}

An attempt was not made to speciate this highly diversified genus in this study. Its stratigraphic distribution in the western Pacific indicates that it is subject to some type of ecological control, because its lowest and highest occurrences vary with locality.

Occurrence: $62-0-2$ to $62-0-1,62-1-9$ to $62-1-6,63-0-2$, $63-1-3$, and $64-0-4$ to $64-0-2$.

\section{Sphenolithus abies}

S. abies dominates nannofloral assemblages in the western Pacific from NN 11 to NN 16. It evolves very gradually from $S$. pacificus within NN 9 and 10 and determination of its lowest occurrence is subjective. It apparently becomes extinct in NN 17, but isolated occurrences were noted in NN 18 and 19.

\section{Sphenolithus belemnos}

Very few specimens of this species observed in the western Pacific conform exactly to the original desscription. Most specimens are less elongate, but all exhibit the characteristic cross in their bases in crosspolarized light when one of the vibration directions is aligned with the long dimension of the specimen. Gradational forms exist which indicate that $S$. heteromorphus evolves from $S$. belemnos through reduction 
of the central spine and formation of a new central spine by elongation and fusion of several of the smaller apical spines. Very large and heavily calcified specimens were observed which resemble $S$. moriformus, except for greater elongation. These produced interference colors up to first order blues and were found near the top of the range of $S$. belemnos. The extinction datum of $S$. belemnos defines the top of NN 3 .

Occurrence: $62-0-5-2,63-0-4,63-1-14-6$ to $63-1-14-2$, 64-0-7 to 64-0-6, and 64-1-6.

\section{Sphenolithus ciperoensis}

Although small, this species is easily recognized by the two chevron-like interference figures with apices facing each other, as seen in cross-polarized light with apical spine $45^{\circ}$ to the vibration directions. This species is rare in the Western Pacific. It was noted from NP 23 and NP 24 and was not found in the Neogene. The lowest occurrence of $S$. ciperoensis defines the base of NP 24 . Occurrence: 63-0-6 and 64-0-8-1.

\section{Sphenolithus distentus}

This species is very common in the Oligocene and the top of its range delineates the bottom of NP 25 .

Occurrence: 62-0-8-core catcher, 63-0-6, 64-0-8, and 64-1-8.

\section{Sphenolithus heteromorphus}

This distinctive sphenolith dominates assemblages from NN 3 through the lower part of NN 5. It evolves from $S$. belemnos in NN 2 and its highest occurrence defines the top of NN 5.

Occurrence: 62-0-4, 62-1-39-core catcher, 63-0-3, 63-114 to $63-1-8-6$, and $64-1-6$ to $64-1-5$.

\section{Sphenolithus predistentus}

$S$. predistentus is common in the western Pacific and appears to be very useful here because it is recognizable even in poorly preserved assemblages.

Occurrence: $62-0-8$-core catcher, $63-0-10$ to $63-0-6$, 64-0-8, and 64-1-8.

\section{Triquetrorhabdulus carinatus}

This easily recognized species is an excellent guide fossil for the western Pacific where it occurs in great abundance. Its lowest occurrence is slightly above the base of NP 24, and its extinction marks the top of NN 2. Occurrence: $62-0-6$ to $62-0-5,63-0-5$ to $63-0-4,63-1$ -

14-6 to $63-0-14-4,64-0-8$ to $64-0-6$, and $64-1-7$.

\section{Triquetrorhabdulus rugosus}

$T$. rugosus is constructed so that it produces no birefringence when it is laying on its side, but it can be easily recognized by its high relief in plain light, and by its dark color in phase contrast illumination. It varies considerably in size and morphology but appears to be a distant descendant of $T$. carinatus even though their ranges do not overlap. Very elongate and narrow objects having weak birefringence were observed to evolve into $T$. rugosus in NN 6. The highest occurrence of $T$. rugosus is within the lower part of NN 11, making it one of the few species which can be used to subdivide this long zone.

Occurrence: $62-0-3$ to $62-0-2,62-1-39-1$ to $62-1-25-5$, 63-0-2, 63-1-8-3 to 63-1-5, and 64-0-4 to 64-0-3.

\section{CORRELATIONS BETWEEN SITES 62, 63 AND 64, AND HIATI FOUND}

Correlations between the calcareous sequences of Sites 62, 63 and 64 shown in Figure 2 are based on boundaries between calcareous nannoplankton zones. The boundary between NN 4 (Helicopontosphaera ampliaperta Zone) and NN 5 (Sphenolithus heteromorphus Zone) has been observed in all sites, although in Hole 64-1 the lower part of Zone NN 5 is missing due to a false hiatus as discussed below. Two additional boundaries can be used to correlate Sites 62 and 63. In both sites the boundary between NN 6 (Discoaster exilis Zone) and NN 7 (Discoaster kugleri Zone) respectively between NN 8 (Catinaster coalitus Zone) and NN 9 (Discoaster hamatus Zone) have been found. These are shown in solid lines in Figure 2. A number of boundaries are found only in one site, as in other sites they are within an interval which was not cored. Such correlations with a lesser degree of certainty are shown in dashed lines in Figure 2.

Boundaries found are:

NN 21/NN 20: $\begin{aligned} 62-1-1-2, & 26-27 \mathrm{~cm} / 62-1-1-\mathrm{CC} \\ 64-0-2-5, & \text { top }\end{aligned}$

NN 19/NN 18: $62-1-4-6, \quad 25-26 \mathrm{~cm} / 62-1-4-6$, $60-61 \mathrm{~cm}$

NN 18/NN 17: $62-1-6-4,125-126 \mathrm{~cm} / 62-1-6-5$, $13-14 \mathrm{~cm}$

NN 17/NN 16: 62-1-7-2, $58-59 \mathrm{~cm} / 62-1-7-2$, $148-149 \mathrm{~cm}$

NN 16/NN 15: $63-2-2-1, \quad 125-126 \mathrm{~cm} / 63-2-2-2$, $100-101 \mathrm{~cm}$

NN 14/NN 13: 62-1-11-1, $25-26 \mathrm{~cm} / 62-1-11-1$, $130-131 \mathrm{~cm}$

NN 13/NN 12: 62-1-13-4, 135-136 cm/62-1-13-5, $25-26 \mathrm{~cm}$

NN 12/NN 11: $62-1-15-5,125-126 \mathrm{~cm} / 62-1-16-1$, $25-26 \mathrm{~cm}$

NN 11/NN 10: $62-1-27-5,125-126 \mathrm{~cm} / 62-1-28-1$, $25-26 \mathrm{~cm}$

NN 10/NN 9: $\quad 62-1-30-6,125-126 \mathrm{~cm} / 62-1-31-1$, $25-26 \mathrm{~cm}$ 


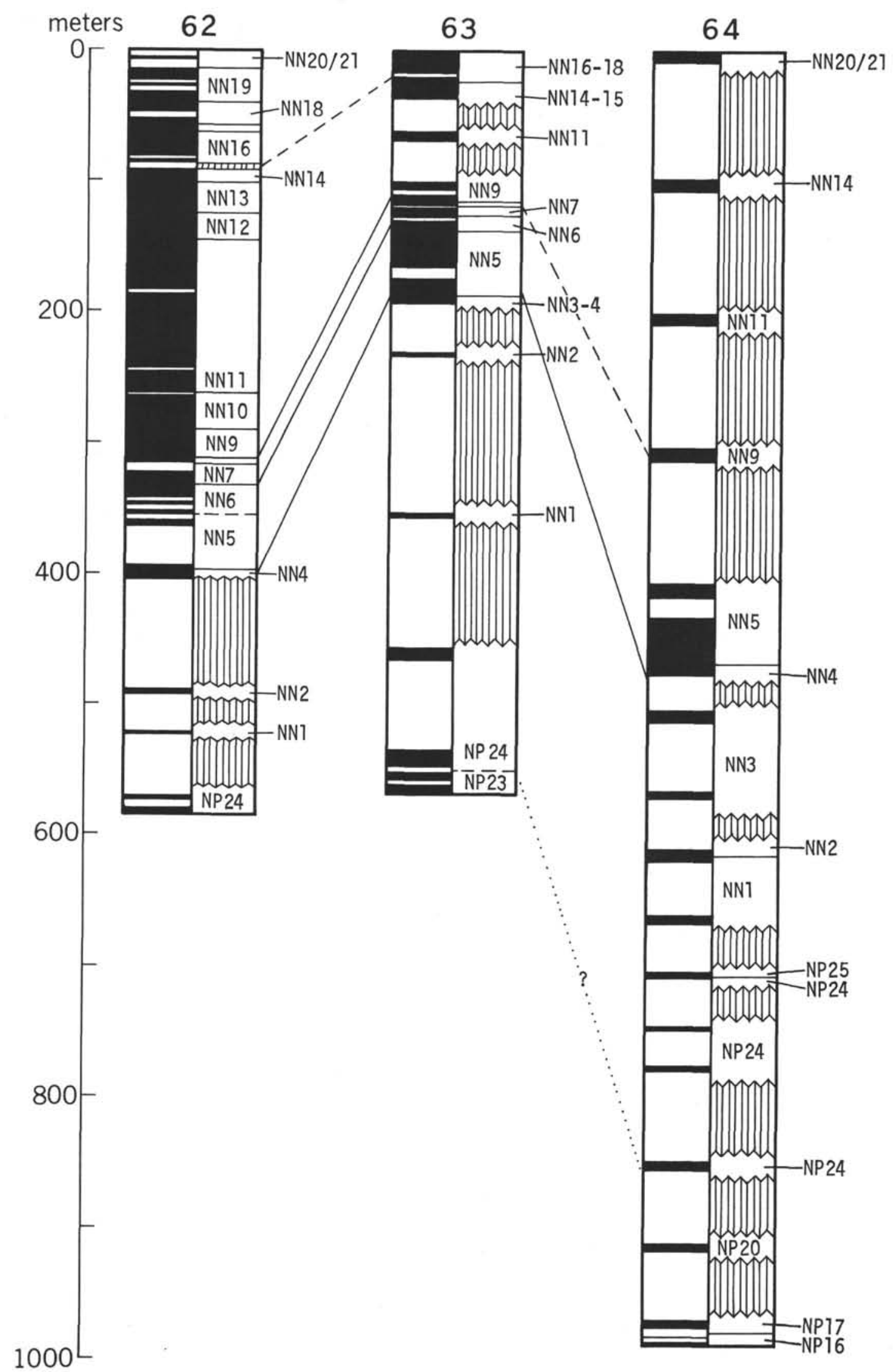

Figure 2. Correlations between Sites 62, 63 and 64, based on calcareous nannoplankton. Left column: recovered material black. Right column: calcareous nannoplankton zones. 
NN 9/NN 8: $62-1-33-3,25-26 \mathrm{~cm} / 62-1-33-3$, $125-126 \mathrm{~cm}$

63-1-6-3, $\quad 25-26 \mathrm{~cm} / 63-1-6-3$, $125-126 \mathrm{~cm}$

NN $8 /$ NN 7:

63-1-6-5, $125-126 \mathrm{~cm} / 63-1-6-6$, $25-26 \mathrm{~cm}$

NN 7 /NN 6: $62-1-35-4,125-126 \mathrm{~cm} / 62-1-35-5$, $25-26 \mathrm{~cm}$

$125-126 \mathrm{~cm}$

63-1-7-4, $\quad 25-26 \mathrm{~cm} / 63-1-7-4$,

NN 6 /NN 5: $\quad 63-1-8-6, \quad 25-26 \mathrm{~cm} / 63-1-8-6$, $125-126 \mathrm{~cm}$

NN $5 / \mathrm{NN} \mathrm{4:} \quad 62-0-4-2, \quad 25-26 \mathrm{~cm} / 62-0-4-2$, $125-126 \mathrm{~cm}$

63-1-13-6, $125-126 \mathrm{~cm} / 63-1-13-\mathrm{CC}$

64-1-2-6, $125-126 \mathrm{~cm} / 64-1-3-1$,

$26-26 \mathrm{~cm}$

NN 4 /NN 3: $\quad 63-1-14-1,125-126 \mathrm{~cm} / 63-1-14-2$, $125-126 \mathrm{~cm}$

NN 3 /NN 2: $63-1-14-3,125-126 \mathrm{~cm} / 63-1-14-4$, $125-126 \mathrm{~cm}$

NN 2 /NN 1: $\quad 64-0-7-3, \quad 130-131 \mathrm{~cm} / 64-0-7-4$, $125-126 \mathrm{~cm}$

NP 25/NP 24: 64-0-8-3, 125-126 cm/64-0-8-CC

In the continuous sequences recovered, three hiati have been found according to missing calcareous nannoplankton assemblages. In Hole $62-1$, Zone NN 15 is missing between Cores 9 and 10; and, in Hole 64-1, the lower part of Zone NN 5 is missing between Core 2 and 3. In both cases the hiati are minor-occur between two cores-indicating that the liner probably was already filled with sediment so that the lowest part of the drilled interval was pushed sidewards. The only true hiatus seem to occur in Hole 65-0, where between Core 14 and 15 the Oligocene/Eocene boundary was penetrated. Between Core 14 (lowest part of Section 3 to bottom of Section 6: Zone NP 21) and Core 15 (Sections 2 to 4 were available: Zone NP 17), the uppermost Eocene (Zones NP 18 to NP 20) apparently is missing, since none of the nannoplankton of these zones was found in the homogenized sediment of Section 2 of Core 15 , which could indicate the presence of the top Eocene.

\section{REGIONAL DISTRIBUTION PATTERN OF CERTAIN SPECIES}

Some genera or species, which were reported as common in other areas, seem to be absent or very rare in the western equatorial Pacific.
In the upper Eocene and lower Oligocene recovered at Sites 64 and 65, Isthmolithus recurvus Deflandre, Zygolithus dubius Deflandre, and related species have not been found in any of the samples. All seem to represent nontropical species, which was already noted for I. recurvus. Lanternithus minutus Stradner, abundant in Upper Eocene-Lower Oligocene samples from Austria, Germany and the east coast of the United States including JOIDES Hole 5, is also absent in all samples, probably due to a preference for near-shore environments.

All species of the genus Helicopontosphaera with the exception of Helicopontosphaera kamptneri Hay and Mohler in the higher part of the column are rare or absent in the Oligocene, and Lower and Middle Miocene of the western equatorial Pacific. Helicopontosphaera ampliaperta (Bramlette and Wilcoxon), indexfossil of Zone $\mathrm{NN} \mathrm{4,} \mathrm{is} \mathrm{absent} \mathrm{in} \mathrm{all} \mathrm{samples} \mathrm{studied;}$ thus, making differentiation between Zone NN 4 and NN 5 difficult. For this reason, the boundary between NN 4 and NN 5 has been chosen in this area by the first appearance of Discoaster exilis Martini and Bramlette, which is believed to appear at approximately the same level at which Helicopontosphaera ampliaperta dies out.

Ceratolithus tricorniculatus Gartner emend. has been reported by Bukry and Bramlette (1968) from various places, including Scripps Core LSDH-78P $\left(4^{\circ} 31^{\prime} \mathrm{S}\right.$, $168^{\circ} 02^{\prime} \mathrm{E}$ ), but is extremely rare in the late Mioceneearly Pliocene at Site 62. "Semidark" forms intermediate between $C$. tricorniculatus Gartner and $C$. rugosus Bukry and Bramlette occur sporadically, however, in the late Miocene of Site 62.

In the early Upper Pliocene the appearance of Coccolithus pelagicus (Wallich) (restricted to forms with a cross-bar), a common species in the recent subarctic floral zone of the Atlantic (McIntyre and Be, 1967), is of some interest. As shown in Figure 3,C. pelagicus shows several peaks of abundance in the interval from the higher part of Zone NN 16 (Discoaster surculus Zone) to the end of Zone NN 18 (Discoaster brouweri Zone), that is, the top of the Pliocene, probably indicating a decrease in water temperature in the western equatorial Pacific during the late Pliocene.

\section{DESCRIPTION OF NEW SPECIES}

Two new species of calcareous nannoplankton with some stratigraphic significance in the Miocene need description and discussion. Both belong to the family Discoasteridae. Type specimens are deposited in the U. S. National Museum, Washington, D. C., Tertiary Catalog No. 132. 


\section{SITE 62}

\section{meters}

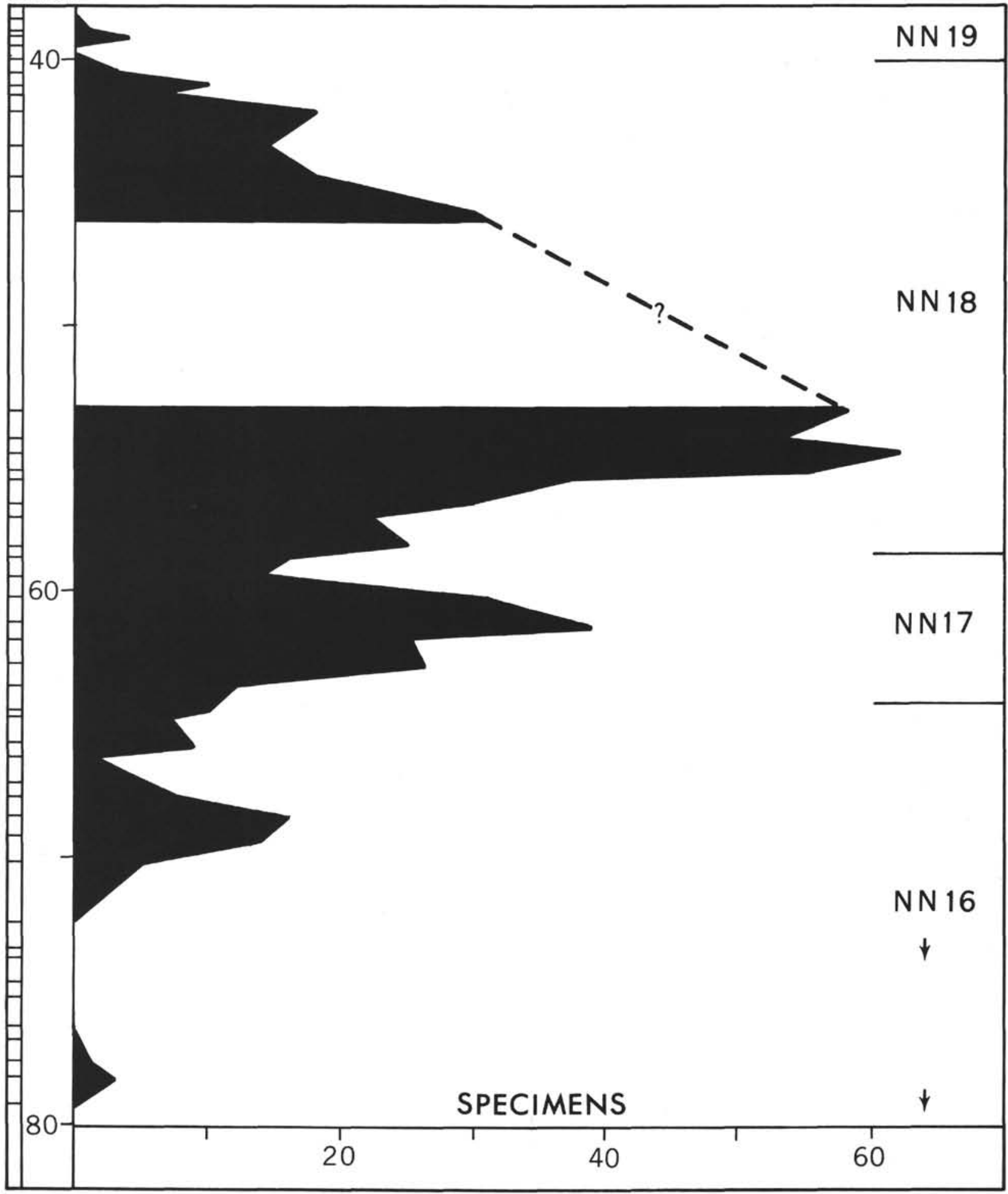

Figure 3. Distribution of Coccolithus pelagicus (Wallich) in the late Pliocene of Hole 62-1 (lower part of Core 4 to Core 8). Left side: samples and meters below seafloor. Right side: calcareous nannoplankton zones. Abscissa: number of specimens per 10 fields (obj. $40 \times$, oc. $12,5 \times$ ). 


\section{Genus Discoaster TAN SIN HOK, 1927 \\ Discoaster formosus, new species Plate 2, Figures 1-7}

Holotype: USNM 651533, Plate 2, Figures 3-4.

Type locality: DSDP 63-1-12-2, 125-126 cm; Miocene, lower part of Sphenolithus heteromorphus Zone (NN 5).

Description: Six- or seven-rayed, rarely five- or fourrayed forms with large central area and a prominent star-shaped knob on one side. Small ridges extend from the knob to the rays, commonly with an offset to the left of the medium-line of rays, as viewed from the stem-side. The rays become slender to their ends and are more or less pointed. The other side (without stem) shows the large central area divided by sutures separating the rays.

Diameter: 15 to 19 microns.

Remarks: Discoaster druggi Bramlette and Wilcoxon is similar in outline, but has no stem, and is common in Zone NN 2.

Distribution: Few or common in DSDP 62-0-4-1, 25 $26 \mathrm{~cm}$ to $62-0-2,25-26 \mathrm{~cm}$, and in DSDP 63-1-11-5, $25-26 \mathrm{~cm}$ to $63-1-13-6,125-126 \mathrm{~cm}$, lower part of Zone NN 5 (Sphenolithus heteromorphus Zone), Miocene.

\section{Discoaster pseudovariabilis, new species} Plate 3, Figures 2-8

Holotype: USNM 651534, Plate 3, Figures 3-4.

Type locality: DSDP 63-1-6-3, 25-26 cm; Miocene, Discoaster hamatus Zone (NN 9).

Description: Six- or rare five-rayed relatively large forms with slender rays, which are bifurcated at the ends. On one side there is a small star-shaped knob with tips pointing towards the rays. Between the bifurcations of the rays a tongue-like projection is pointing slightly downwards. In the lower part of its occurrence the projection is short with two dentlike tips, but is commonly more prominent in the upper part of the occurrence of the species.

Diameter: 16 to 23 microns.

Remarks: $D$. pseudovariabilis is related to $D$. variabilis Martini and Bramlette, which has "web-like" structures between the bifurcations of rays, but without tongue-like projections. A similar species is $D$. subsurculus Gartner from the Globorotalia fohsi lobata and robusta Zones of the Cipero Formation in Trinidad (approximately equivalent to NN 7 and $\mathrm{NN}$ 6), but is smaller, has shorter rays and a rather large central area as compared with the length of rays.

Distribution: Few or common in DSDP 63-1-5-2, 125 $126 \mathrm{~cm}$ to 63-1-6-5, Zones NN 9 to NN 8/(Discoaster hamatus Zone and Catinaster coalitus Zone), Miocene.

\section{REFERENCES}

Bramlette, M. N., 1961. Pelagic sediments. In Oceanography. Sears, M. (Ed.) Publ. Am. Assoc. Adv. Sci., 67, 345 .

Bramlette, M. N. and Wilcoxon, J. A., 1967. Middle Tertiary calcareous nannoplankton of the Cipero Section, Trinidad, W. I. Tulane Stud. Geol. $5(3), 93$.

Bukry, D. and Bramlette, M. N., 1968. Stratigraphic significance of two genera of Tertiary calcareous nannoplankton. Tulane Stud. Geol. 6 (4), 149.

Gartner, S., 1967. Calcareous nannofossils from Neogene of Trinidad, Jamaica, and Gulf of Mexico. Univ. Kansas Paleont. Contr. Paper 29, 1.

1968. Coccoliths and related calcareous nannofossils from Upper Cretaceous deposits of Texas and Arkansas. Kansas Univ. Paleont. Contr. Protista Art. 1.

1969. Correlation of Neogene planktonic foraminifer and calcareous nannoplankton zones. Trans. Gulf Coast Assoc. Geol. Soc. 19, 585.

Haq, U. Z. B., 1969. The structure of Eocene coccoliths and discoasters from a Tertiary deep-sea core in the Central Pacific. Acta Univ. Stockholm., Stockholm Contr. Geol. 21 (1), 1.

Hay, W. W., 1970. Calcareous nannofossils from cores recovered on DSDP Leg 4, Bader, R. G., et al. (1970) Initial Reports of the Deep Sea Drilling Project, Volume IV. Washington (U. S. Government Printing Office). (in press).

Hay, W. W., Mohler, H. P., Roth, P. H., Schmidt, R. R. and Boudreaux, J. E., 1967. Calcareous nannoplankton zonation of the Cenozoic of the Gulf Coast and Caribbean-Antillean area and transoceanic correlation. Trans. Gulf Coast Assoc. Geol. Soc. 17, 428.

Kamptner, E., 1963. Coccolithineen-Skelettreste aus Tiefseeablagerungen des Pazifischen Ozeans. Ann. Naturhist. Mus. Wien. 66, 139.

Loeblich, A. R., Jr. and Tappan, H., 1966. Annotated index and bibliography of the calcareous nannoplankton. II. Phycologia. 5, 81.

1968. Annotated index and bibliography of the calcareous nannoplankton. J. Paleont. 42, 584.

1969. Annotated index and bibliography of the calcareous nannoplankton. III. J. Paleont. 43, 568.

Martini, E., 1965. Mid-Tertiary calcareous nannoplankton from Pacific deep-sea cores. In Submarine Geology and Geophysics. Whittard, W. F. and Bradshaw, R. B. (Eds.). Proc. 17th Symp. Colston Research Soc. London (Butterworths), 393.

1970. Standard Palaeogene calcareous nannoplankton zonation. Nature. 225 (5229), 289.

Martini, E. and Bramlette, M. N., 1963. Calcareous nannoplankton from the experimental Mohole drilling. J. Paleont. $37,845$.

Martini, E. and Worsley, T., 1970. Standard Neogene calcareous nannoplankton zonation. Nature. 225, 289. 
McIntyre, A. and Be, A. W. H., 1967. Modern Coccolithophoridae of the Atlantic Ocean.-I. Placoliths and Cyrtoliths. Deep-Sea Res. 14, 561.
Riedel, W. R. and Funnell, B. M., 1964. Tertiary sediment cores and microfossils from the Pacific Ocean floor. Quart. J. Geol. Soc. London. 120, 305. 


\section{PLATE 1}

Figure $1 \quad$ Scapholithus fossilis Deflandre

DSDP 64-0-1-6-top, Quaternary, Zone NN20.

Stereoscan, 65,500 X.

Figure 2 Gephyrocapsa oceanica Kamptner

DSDP 64-0-1-5-top, Quaternary, Zone NN20.

Stereoscan, $16,000 \times$.

Figures 3 \& $4 \quad$ Emiliania huxleyi (Lohmann) Hay and Mohler DSDP 64-0-1-3-top, Quaternary, Zone NN21.

Stereoscan, $26,000 \times(3), 27,000 \times(4)$. 
Plate 1
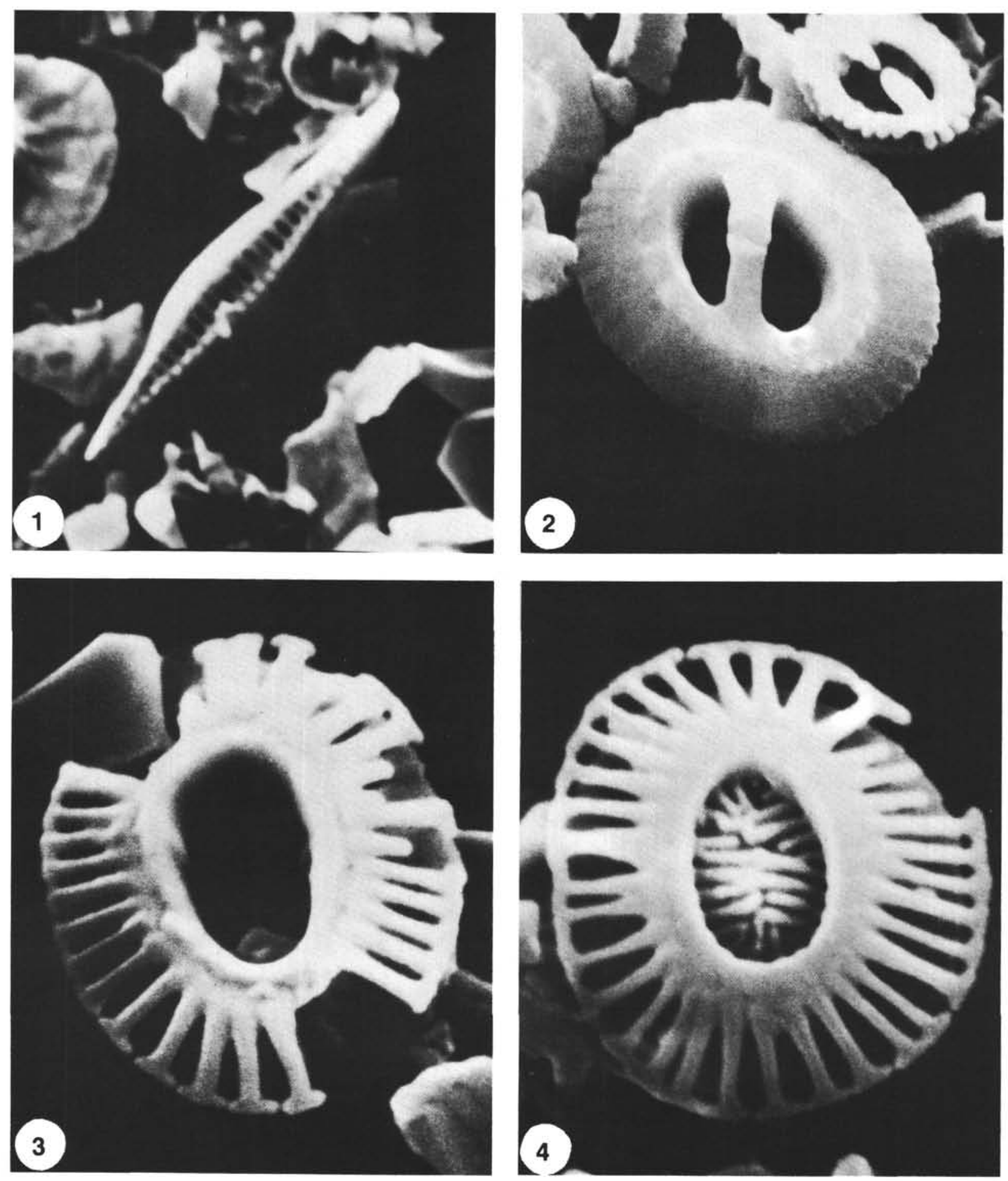
PLATE 2

Figures 1-8 Discoaster formosus, new species

1 6-rayed specimen, stem-side, Stereoscan, 11,000 X.

2 6-rayed specimen, stemless-side, Stereoscan, 12,500 X. 1\&2 DSDP 63-1-13-5-top, Miocene, Zone NN 5.

3 \& 4 6-rayed specimen, stem-side, Holotype USNM 651533.

3. medium focus

4. high focus

6-rayed specimen, stemless-side.

6 6-rayed tilted specimen showing the stem.

$7 \& 8 \quad$ 7-rayed specimen, stem-side

7. medium focus

8. high focus

3-8 DSDP 63-1-12-2, 125-126 cm, Miocene, Zone NN 5. Light micrographs, $2000 \mathrm{X}$. 
PLATE 2
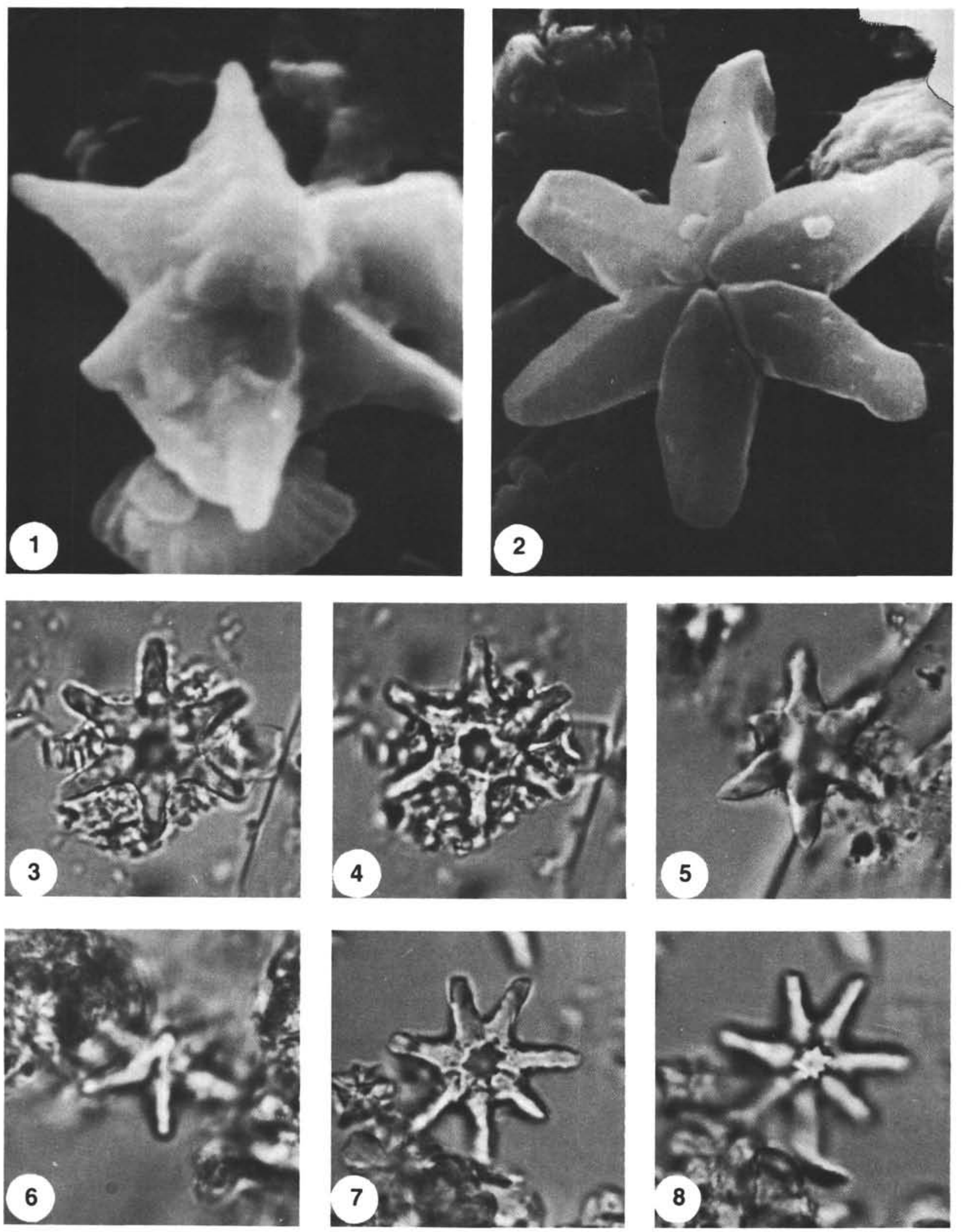


\section{PLATE 3}

Figure 1 Discoaster cf. formosus, new species 6-rayed specimen, stem-side, Stereoscan, $7400 \times$ DSDP 63-1-13-5-top, Miocene, Zone NN 5.

Figures 2-8 Discoaster pseudovariabilis, new species

2 6-rayed specimen, phase contrast, $2500 \mathrm{X}$. DSDP

3 \& 4 6-rayed specimen, Holotype USNM 651534.

3. high focus

4. medium focus

$5 \& 6 \quad$ 6-rayed specimens.

$7 \& 8 \quad$ 5-rayed specimen.

7. high focus

8. medium focus

3-8 DSDP 63-1-6-3, 25-26 cm, Miocene, Zone NN 9. Light-micrographs, $2000 \mathrm{X}$. 


\section{PLATE 3}
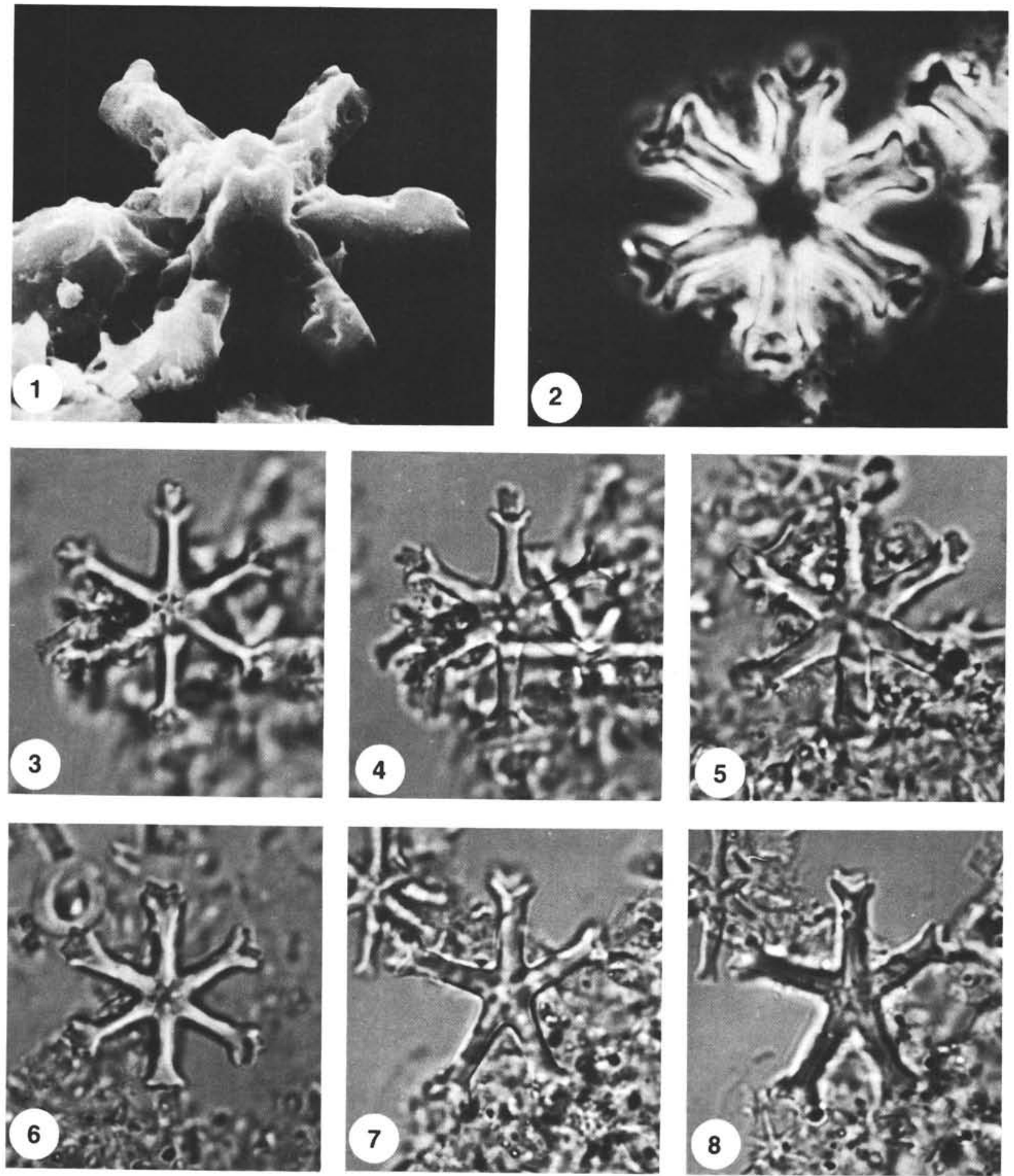